\title{
Health Risk Assessment of Some Heavy Metals in Water and Sediment at Marsa-Matrouh, Mediterranean Sea, Egypt
}

\author{
Azza Khaled ${ }^{1 *}$, Ahmed Abdel-Halim², Zeinab El-Sherif ${ }^{3}$, Laila A. Mohamed ${ }^{2}$ \\ ${ }^{1}$ Marine Pollution Research Department, Environmental Division, National Institute of Oceanography and Fisheries, Alexandria, \\ Egypt \\ ${ }^{2}$ Marine Chemistry Department, Environmental Division, National Institute of Oceanography and Fisheries, Alexandria, Egypt \\ ${ }^{3}$ Hydrobiology Department, Environmental Division, National Institute of Oceanography and Fisheries, Alexandria, Egypt \\ Email: *lailamsus@yahoo.com
}

How to cite this paper: Khaled, A., AbdelHalim, A., El-Sherif, Z. and Mohamed, L.A. (2017) Health Risk Assessment of Some Heavy Metals in Water and Sediment at Marsa-Matrouh, Mediterranean Sea, Egypt. Journal of Environmental Protection, 8, 7497.

http://dx.doi.org/10.4236/jep.2017.81007

Received: November 22, 2016

Accepted: January 22, 2017

Published: January 25, 2017

Copyright () 2017 by authors and Scientific Research Publishing Inc. This work is licensed under the Creative Commons Attribution International License (CC BY 4.0).

http://creativecommons.org/licenses/by/4.0/ (c) (i) Open Access

\begin{abstract}
In an attempt to evaluate the environmental quality of Marsa-Matrouh city which covered the most famous beaches in Egypt, an environmental risk assessment was performed, including a screening level ecological risk assessment. The aim of this work was to determine which metals could possibly pose toxic adverse ecological effects to marine organisms and to determine whether hot spots exist or not. To fulfill the goals of study, surfacial sediment and water samples were collected from ten different locations covering MarsaMatrouh city during four seasons (2010-2011). The average concentrations of $\mathrm{Cd}, \mathrm{Cu}, \mathrm{Fe}, \mathrm{Ni}, \mathrm{Pb}$ and $\mathrm{Zn}$ were $2.381 \pm 3.389,9.307 \pm 14.159,68.969 \pm 9.397$, $2.642 \pm 1.004,16.712 \pm 8.469,31.168 \pm 15.322 \mu \mathrm{g} / \mathrm{l}$ in water and $0.755 \pm 0.240$, $5.363 \pm 1.581,962.131 \pm 975.084,3.972 \pm 2.180,15.210 \pm 4.434$ and $24.608 \pm$ $7.706 \mu \mathrm{g} / \mathrm{g}$ dry weight in sediment respectively. The concentrations of the investigated six metals in water were within the acceptable limits except for two stations (Cleopatra and El-Obayed) which exhibited higher values than the permissible level of Cd during autumn 2010. Metal pollution assessment for both water and sediment was studied. Heavy metal pollution index indicates that water is not critically polluted with respect to the investigated metals. For sediment samples, threshold effect concentrations (TEC HQ) were lower than 1 except for Cd which showed higher value than 1, indicating the possibility of occurrence of toxic adverse ecological effects to benthic organisms for $\mathrm{Cd}$, while rare adverse ecological effects are expected to occur with respect to $\mathrm{Cu}$, $\mathrm{Ni}, \mathrm{Pb}$ and $\mathrm{Zn}$.
\end{abstract}

\section{Keywords}

Trace Metal, HQ, Human Health Risk, Marsa-Matrouh, Mediterranean Sea, Egypt 


\section{Introduction}

Metals are naturally occurring elements that ultimately originate from weathering of rock substrates. These metals are mainly chemically bound to alumino-silicates and are therefore not readily bio-available [1]. In contrast to the natural occurring of metals, the anthropogenic origin of these metals is more readily available to organisms due to the fact that they are more loosely bound in sediments [2]. One of the most crucial properties of heavy metals is that they are not biodegradable in the environment. In marine ecosystems, sediments show a great capacity to accumulate and integrate heavy metals and organic pollutants even from low concentrations in the overlying water column [3] [4] [5] [6] and so it acts as the main sink for metals [7] [8] and other pollutants [9]. Although most pollutants adsorbed on the sediments are not bioavailable, certain mechanisms may induce the release of pollutants back to the water column including sediment resuspension, desorption, redox reactions or (bio-)degradation of the sorptive substance [10] [11] [12] [14] [15] that can have toxic adverse effects on living organisms [16] [17] [18]. As a combined result of these factors, metal concentrations in the sediment change in space and time. In fact, during the last few decades, industrial and urban activities have contributed to the increase of metals contamination into marine environment and have directly influenced the coastal ecosystems [19]. Interactions between solid sedimentary matter and dissolved metals play an important role in the regulation of dissolved metal concentrations (which are the most bioavailable) in the water [20].

The Marsa-Matrouh City has an area of 212,112 $\mathrm{km}^{2}$ and 193,000 inhabitants, or 0.9 in habitants $/ \mathrm{km}^{2}$ [21]. The town of Marsa-Matrouh is the only important town on the 500 kilometers long stretch of the Mediterranean coast between Alexandria and the Libyan border. In summer, the number of visitors to MarsaMatrouh increases (more than one million visitors enjoy the beautiful white sand beaches and clear seawater), and hence the human activity in this site increases which reflects the changing in the environmental conditions.

The main aim of this work was to determine the spatial variations of $\mathrm{Cd}, \mathrm{Cu}$, $\mathrm{Ni}, \mathrm{Zn}$ and $\mathrm{Fe}$ contents in water and sediment samples collected from MarsaMatrouh City. The samples were collected from ten beaches along the MarsaMatrouh coast which were selected to cover the most famous beaches to estimate the degree of contamination by using heavy metal pollution index for water and the geo-accumulation index, enrichment factor and the modified degree of contamination for sediment.

\section{Materials and Methods}

Seasonal water and sediment samples were collected from ten beaches (ElRemelah, Alam El-Roum, Mena Hashesh, El-Fayrouz, Romel, El-Boseet, Cleopatra, El-Gharam, El-Obayed and Ageba) during (2010-2011), which covered approximately $500 \mathrm{Km}$ from the Egyptian Mediterranean coastline. Location of the sampling points was showed in Figure 1 and Table 1. 


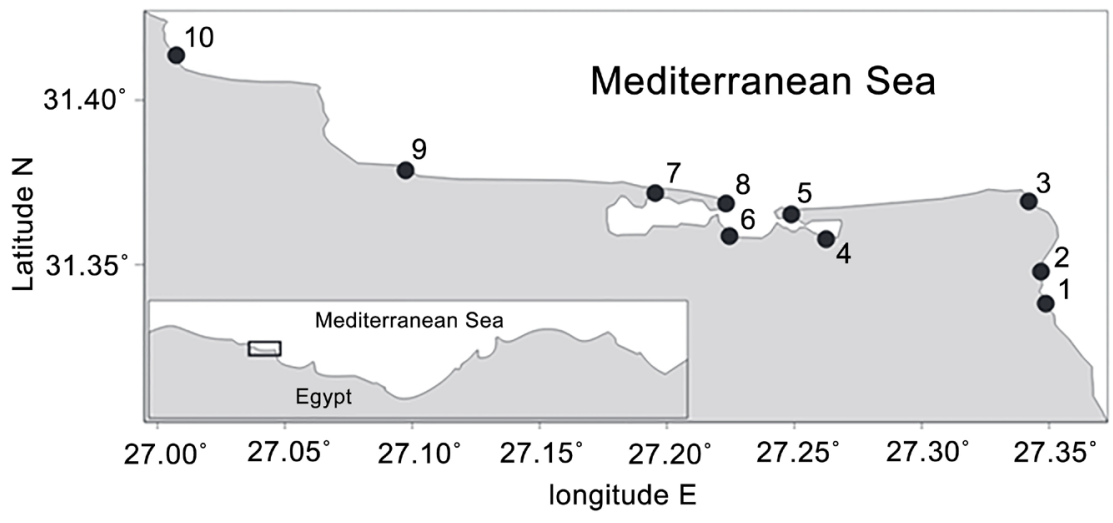

Figure 1. Sampling locations of Marsa-Matrouh, Egyptian mediterranean sea coast.

Table 1. Sampling locations of Marsa-Matrouh Beaches.

\begin{tabular}{cccc}
\hline Station & Location & Latitude (N) & Longitude (E) \\
\hline 1 & El-Remelah & $31^{\circ} 20^{\prime} 16.7^{\prime \prime}$ & $27^{\circ} 20^{\prime} 53.2^{\prime \prime}$ \\
2 & Alam El-Roum & $31^{\circ} 20^{\prime} 16.7^{\prime \prime}$ & $27^{\circ} 20^{\prime} 50.1^{\prime \prime}$ \\
3 & Mena-Hashish & $31^{\circ} 22^{\prime} 6.7^{\prime \prime}$ & $27^{\circ} 20^{\prime} 30.1^{\prime \prime}$ \\
4 & El-Fayroz & $31^{\circ} 21^{\prime} 28.8^{\prime \prime}$ & $27^{\circ} 15^{\prime} 46.6^{\prime \prime}$ \\
5 & Romel & $31^{\circ} 21^{\prime} 55.4^{\prime \prime}$ & $27^{\circ} 14^{\prime} 55.5^{\prime \prime}$ \\
6 & El-Boseet & $31^{\circ} 21^{\prime} 32.5^{\prime \prime}$ & $27^{\circ} 133^{\prime} 29.1^{\prime \prime}$ \\
7 & Cleopatra & $31^{\circ} 22^{\prime} 17.3^{\prime \prime}$ & $27^{\circ} 111^{\prime} 44.8^{\prime \prime}$ \\
8 & El-Gharam & $31^{\circ} 22^{\prime} 6.5^{\prime \prime}$ & $27^{\circ} 13^{\prime} 24.7^{\prime \prime}$ \\
9 & El-Obayed & $31^{\circ} 222^{\prime} 45.7^{\prime \prime}$ & $27^{\circ} 5^{\prime} 45.6^{\prime \prime}$ \\
10 & Ageba & $31^{\circ} 24^{\prime} 46.3^{\prime \prime}$ & $27^{\circ} 0^{\prime} 24.2^{\prime \prime}$ \\
\hline
\end{tabular}

Coastal water samples were collected from the ten stations using Nansen bottles at $2 \mathrm{~m}$ depth, and then, stored in acid-washed polyethylene bottles until analysis. All the precautions recommended by [22] to minimise risks of sample contamination were followed during collection and treatment of samples. Dissolved heavy metals were determined according to [23], as modified by [24]. Water samples were filtered immediately after collection using pre-acid cleaned Millipore membrane filters $(0.45 \mathrm{~mm}$ pore size; $47 \mathrm{~mm}$ diameter). The filtrates were acidified to $\mathrm{pH} 2$, with $\mathrm{HNO}_{3}$ of supra pure grade; they were stored, in acid-cleaned high-density polyethylene bottles, in plastic bags. The samples were passed through columns filled with an ion exchange resin (Chelex-100, mesh 200 - 400), via a peristaltic pump in a clean air laboratory. After removal of the alkalis, the metals were eluted from the resin with a mixture of $2 \mathrm{~N} \mathrm{HNO}_{3}: 1 \mathrm{~N} \mathrm{HCl}$ (1:3). A 100-fold pre-concentration factor was achieved. Trace metal concentrations were determined in elutes.

The surface samples (about $1 \mathrm{Kg}$ ) were collected from the ten beaches with the water samples from the same places at $(3-5 \mathrm{~cm})$ depth during the four seasons. Sediment samples were collected using a Van-Veen grab coated with polyethy- 
lene [25]. Sediment sampling location position was detected using GPS localisation. Subsamples were taken from the central part of the grab to avoid contamination. The samples were kept in self-sealed acid pre-cleaned plastic bags, rinsed with metal-free water. The samples were deep-frozen until analysis. The samples were dried in the oven at $50^{\circ} \mathrm{C}$ under vacuum (Medline-OV-12) and sieved, using plastic sieve to separate the shells and stones, crushed and homogenized prior to the analysis. The heavy metals in bottom sediments were digested according to the method described by [26]. An exact weight of dry sample (about $0.2 \mathrm{~g}$ ) was placed in Teflon beaker, $3 \mathrm{ml}$ of concentrated nitric acid was added to the sample and evaporated to dryness at $80^{\circ} \mathrm{C}, 5 \mathrm{ml}$ of $\mathrm{HNO}_{3} / \mathrm{HClO}_{4} / \mathrm{HF}$ mixture (3:2:1) was added to each sample. After complete digestion, the sample was evaporated to dryness; the temperature was increased gradually to $120^{\circ} \mathrm{C}$ to remove the $\mathrm{HClO}_{4}$ residue. The sample was cooled at room temperature and $5 \mathrm{ml}$ of 0.1 $\mathrm{N} \mathrm{HCl}$ was used to rinse and transfer the residue to $25 \mathrm{ml}$ volumetric flask. The metals concentrations were determined by AAS (Shimadzu, AA-6800) and the results were expressed in $\mu \mathrm{g} / \mathrm{l}(\mathrm{ppb})$ for water samples and $\mu \mathrm{g} / \mathrm{g}$ (ppm) dry weights for sediment samples, $\mathrm{Cd}$ and $\mathrm{Pb}$ were analysed by graphite furnace and $\mathrm{Ni}, \mathrm{Cu}, \mathrm{Zn}$ and $\mathrm{Fe}$ by flame.

\subsection{Assessment of Metal Pollution}

\subsubsection{Heavy Metal Pollution Index}

Heavy metal pollution index (HPI) is a technique of rating that provides the composite influence of individual heavy metal on the overall quality of water. The rating is a value between zero and one, reflecting the relative importance of individual quality considerations and inversely proportional to the recommended standard (Si) for each parameter [27] [28] [29]. The heavy metal pollution index (HPI) were calculated by the Equation:

$$
\mathrm{HPI}=\frac{\sum_{i=1}^{n}(\mathrm{QiWi})}{\sum_{i=1}^{n}(\mathrm{Wi})}
$$

where Qi is the sub-index of $i$ th parameter, Wi is the unit weightage for $i$ th parameter (calculated according to [30], $n$ is the number of parameters considered. The critical pollution index value is 100 .

\subsubsection{Sediment Quality Guidelines (SQGs)}

The effect characterization was based on several sets of sediment quality guidelines (SQGs) reported in literature. Some authors have developed the consensus based approach trying to harmonize the existing values [31] [32] [33], which was used in the present study for the risk calculations and for pointing out the presence of any hot spots in Marsa-Matrouh City. In the consensus approach (CA), consensus-based SQGs are derived from the existing SQGs that have been established for the protection of sediment-dwelling organisms. First, the SQGs for the protection of sediment-dwelling organisms are grouped into two categories according to their original narrative intent, including threshold effect concentrations (TECs) and probable effect concentrations (PECs). TECs group are in- 
tended to identify concentrations below which harmful effects on sedimentdwelling organisms are unlikely to be observed, included effect range low (ERL) [34], threshold effect level (TEL) [35] [36] and logistic regression models including T20, which represents the probability of occurrence of adverse ecological effects in $20 \%$ of the investigated samples (T20) [37]. The PECs are intended to identify concentrations above which harmful effects on sediment-dwelling organisms are likely to be frequently or always observed [31] [33], included probable effect level (PEL) [35] [36] [38], effect range medium (ERM) [34] [35] [36], logistic regression models including T50, which represents the probability of occurrence of adverse ecological effects in 50\% of the investigated samples [37] and the apparent effect threshold low (AET-L) [39]. For some sediment quality guidelines, values representing higher level of adverse ecological effects are available (T80 and AET-H), where extreme adverse ecological effects could be expected as showed in Table 2 .

\subsubsection{Hazard Quotient}

In the present study, the risk was characterized by comparing the maximum concentration of each pollutant with its corresponding sediment quality guideline. The selected approach was the hazard quotient (HQ). Two HQs were calculated for each pollutant; TEC HQ which was calculated by dividing the maximum concentration of each pollutant by the calculated consensus-based TEC (CBSQGTEC) and the PEC HQ, which was calculated by dividing the maximum concentration of each pollutant by the calculated consensus-based PEC (CBSQGPEC). When TEC HQ $<1$ for a given pollutant, rare adverse ecological effects are expected to occur with respect to this pollutant, when PEC HQ $>1$, frequent adverse ecological effects are expected to occur and when TEC HQ $>1>$ PEC HQ, adverse ecological effects are possible but less frequent than the previous level.

$$
\begin{aligned}
& \text { TEC HQ }=\frac{\text { Concentration of the pollutant }}{\text { CBSQG }_{\mathrm{TEC}}} \\
& \text { PEC HQ }=\frac{\text { Concentration of the pollutant }}{\text { CBSQG }_{\mathrm{PEC}}}
\end{aligned}
$$

\subsubsection{Geoaccumulation Index}

[40] defined Geoaccumulation index (Igeo) in order to determine metals contamination in sediments. To compare the current concentration with pre-industrial levels, Igeo was calculated by the following Equation:

$$
\text { Igeo }=\log 2[\mathrm{Cn} /(1.5) \mathrm{Bn}]
$$

where $\mathrm{Cn}$ is the measured concentration of the studied metal " $\mathrm{n}$ " in the sediment and $\mathrm{Bn}$ is the geochemical background concentration of the metal " $\mathrm{n}$ ". Factor 1.5 is used because of possible variations in background values for a given metal in the environment, as well as very small anthropogenic influences. Müller had distinguished seven classes of geoaccumulation index [41] as described in Table 3. 
Table 2. Summary of the effect concentration levels from different SQGs.

\begin{tabular}{ccccccc}
\hline \multirow{2}{*}{ Effect } & & \multicolumn{5}{c}{ Metal $(\mu \mathrm{g} / \mathrm{g} \mathrm{dw})$} \\
\cline { 3 - 6 } & & $\mathrm{Cd}$ & $\mathrm{Cu}$ & $\mathrm{Ni}$ & $\mathrm{Pb}$ & $\mathrm{Zn}$ \\
\hline \multirow{2}{*}{$\begin{array}{c}\text { Threshold } \\
\text { Effect }\end{array}$} & ERL & 1.20 & 34.0 & 20.9 & 46.7 & 150.0 \\
& TEL & 0.68 & 18.7 & 15.9 & 30.2 & 124.0 \\
& T20 & 0.38 & 32.0 & 15.0 & 30.0 & 94.0 \\
& TEC & $\mathbf{0 . 7 0}$ & $\mathbf{2 7 . 3}$ & $\mathbf{1 7 . 1}$ & $\mathbf{3 4 . 8}$ & 121.0 \\
\hline \multirow{3}{*}{$\begin{array}{c}\text { Probable } \\
\text { Effect }\end{array}$} & ERM & 9.60 & 270.0 & 51.0 & 218.0 & 410.0 \\
& PET-L & 2.70 & 390.0 & 110.0 & 430.0 & 460.0 \\
& T50 & 1.40 & 94.0 & 47.0 & 94.0 & 240.0 \\
& PEC & $\mathbf{3 . 5 0}$ & 181.0 & $\mathbf{5 8 . 1}$ & $\mathbf{1 7 7 . 0}$ & $\mathbf{3 3 3 . 0}$ \\
\hline \multirow{2}{*}{$\begin{array}{c}\text { Extreme } \\
\text { Effect }\end{array}$} & AET-H & 14.00 & 1300 & 371 & 1200 & 3800 \\
& T80 & 4.90 & 280 & 150 & 300 & 640 \\
\hline & EEC & $\mathbf{8 . 3 0}$ & $\mathbf{6 0 3}$ & $\mathbf{2 3 6}$ & $\mathbf{6 0 0}$ & $\mathbf{1 5 6 0}$ \\
\hline
\end{tabular}

Table 3. Igeo classification according to Müller, 1981.

\begin{tabular}{ccl}
\hline Igeo & Igeo class & Designation of sediment quality \\
\hline$>5$ & 6 & Extremely contaminated \\
$4-5$ & 5 & Strongly to extremely contaminated \\
$3-4$ & 4 & Strongly contaminated \\
$2-3$ & 3 & Moderately to strongly contaminated \\
$1-2$ & 2 & Moderately contaminated \\
$0-1$ & 1 & Uncontaminated to moderately contaminated \\
$<0$ & 0 & Uncontaminated \\
\hline
\end{tabular}

\subsection{Statistical Analysis}

Spearman (non-parametric) rank order correlations, Principal component analysis (PCA) and cluster analysis (CA) are the most common multivariate statistical methods used in environmental studies [42]-[48]. In the present study, SPSS for Windows, Version 15, was utilized for the multivariate analysis and for correlation analysis.

\subsubsection{Principal Component Analysis}

Multivariate analysis (Principal component analysis, PCA) has been applied on the data set for ten sediment samples and six variables $(\mathrm{Cd}, \mathrm{Cu}, \mathrm{Pb}, \mathrm{Ni}, \mathrm{Zn}$, and Fe). R-mode factor analysis with VARIMAX rotation with Kaiser Normalization, as well as the Eigen values was applied to the previous metals in the sediment samples.

\subsubsection{Cluster Analysis}

Hierarchical cluster analysis (HCA) was carried out using the average linkage clustering which was applied on the Pearson correlation for the four groups of 
pollutants under investigation. This dendrogram was confirmed by applying two other clustering methods: This dendrogram was confirmed by applying two other clustering methods: 1) Complete linkage, using the cluster method further neighbor with interval Pearson correlation, 2) Centroid linkage, with the interval Pearson correlation.

\section{Results and Discussion}

\subsection{Water}

The distribution of heavy metal concentrations for the ten beaches of the investigated area were reported in Table 4 and Table 5.

The dissolved cadmium concentration in water of Marsa-Matrouh beaches ranged between $0.168 \mu \mathrm{g} / \mathrm{l}$ determined at El-Obayed during summer 2011 and 48.977 at Cleopatra during autumn 2010. The average concentration of $\mathrm{Cd}$ in the five trips under investigation was increased in the order of winter $2011>$ spring $2011>$ summer $2011 \approx$ summer $2010>$ autumn 2010, with the total annual average of $2.381 \pm 3.389 \mu \mathrm{g} / \mathrm{l}$ which exceed the natural concentration of seawater $(0.1 \mu \mathrm{g} / \mathrm{l})$ according to [49]. All the concentrations of $\mathrm{Cd}$ in the present study recorded lower concentrations than the [50] $(5 \mu \mathrm{g} / \mathrm{l})$ except the two stations Cleopatra and Obayed in autumn 2010 which exhibited higher values (48.977 and $48.977 \mu \mathrm{g} / \mathrm{l}$ respectively).

The concentrations of dissolved copper in the investigated beaches were fluctuated between 1.701 at Agiba station in winter 2011 and $148.050 \mu \mathrm{g} / \mathrm{l}$ at El-Obayed during autumn 2010. Based on the annual average concentration of copper in Marsa-Matrouh beaches, it was $9.307 \pm 14.159 \mu \mathrm{g} / \mathrm{l}$ which is higher than that of natural sea water concentration $(2 \mu \mathrm{g} / \mathrm{l})$ according to [49] but it was within the acceptable limits $(5-112 \mu \mathrm{g} / \mathrm{l})$ for all stations in the investigated area except station El-Obayed during autumn 2010 which recorded a relatively higher value $(148.050 \mu \mathrm{g} / \mathrm{l})$ according to the [51] of heavy metals. Copper recorded the highest level during autumn 2010 followed with that recorded in spring 2011 while the lowest value was recorded during winter 2010. The lower value of $\mathrm{Cu}$ in winter may be due to the low organic matter degradation. Similar to that observed for Cd, copper recorded nearly similar values during the two overlapping summer seasons (5.514 and $5.946 \mu \mathrm{g} / \mathrm{l}$ for 2010 and 2011 respectively).

Iron is present in very low iron concentrations in the oceans, despite its enhanced abundance in the earth's crust, and is a vital constituent of plant life [52]. It found in the natural sea water at level of $2 \mu \mathrm{g} / \mathrm{l}$. in the present study, the dissolved iron concentration was fluctuated between 15.167 and $158.445 \mu \mathrm{g} / \mathrm{l} \mathrm{rec-}$ orded at El-Remelah and El-Gharam stations during autumn and spring, respectively with an annual average of $68.969 \pm 9.397 \mu \mathrm{g} / \mathrm{l}$. It was noted that the dissolved iron concentrations recorded in the Matrouh Beaches were lower than the permissible Limits $(300 \mu \mathrm{g} / \mathrm{l})$ according to the Canadian acceptable limits [53]. The highest average concentration of Fe was recorded during spring 2011 followed by summer 2010 and 2011 while the lower value was observed during autumn 2010. 
Table 4. Distribution of $\mathrm{Cd}, \mathrm{Cu}$ and $\mathrm{Pb}(\mu \mathrm{g} / \mathrm{L})$ concentrations in different water samples collected from Marsa-Matrouh beaches during 2010-2011.

\begin{tabular}{|c|c|c|c|c|c|c|}
\hline \multirow{2}{*}{ Station } & \multicolumn{2}{|c|}{2010} & \multicolumn{3}{|c|}{2011} & \multirow{2}{*}{$\begin{array}{l}\text { Annual } \\
\text { Average }\end{array}$} \\
\hline & Summer & Autumn & Winter & Spring & Summer & \\
\hline \multicolumn{7}{|c|}{ Cadmium $(\mu \mathrm{g} / \mathrm{L})$} \\
\hline El-Remelah & 1.587 & 0.747 & 0.192 & 0.588 & 0.441 & 0.711 \\
\hline Alam El-Roum & 0.747 & 0.747 & 0.401 & 0.603 & 0.341 & 0.568 \\
\hline Mena-Hashish & 2.007 & 2.147 & 0.320 & 0.603 & 0.192 & 1.054 \\
\hline El-Fayroz & 0.397 & 0.583 & 0.657 & 1.176 & 2.793 & 1.121 \\
\hline Romel & 0.397 & 0.817 & 0.371 & 0.834 & 1.610 & 0.806 \\
\hline El-Boseet & 4.200 & 2.753 & 0.320 & 0.699 & 1.797 & 1.954 \\
\hline Cleopatra & 0.280 & 48.977 & 0.488 & 0.792 & 2.933 & 10.694 \\
\hline El-Gharam & 0.373 & 0.607 & 0.572 & 0.185 & 0.365 & 0.420 \\
\hline El-Obayed & 0.280 & 29.563 & 0.422 & 0.285 & 0.168 & 6.144 \\
\hline Ageba & 0.397 & 0.513 & 0.204 & 0.350 & 0.252 & 0.343 \\
\hline Min & 0.280 & 0.513 & 0.192 & 0.185 & 0.168 & 0.343 \\
\hline $\operatorname{Max}$ & 4.200 & 48.977 & 0.657 & 1.176 & 2.933 & 10.694 \\
\hline Average & 1.067 & 8.745 & 0.395 & 0.612 & 1.089 & 2.381 \\
\hline \multicolumn{7}{|c|}{ Copper $(\mu \mathrm{g} / \mathrm{L})$} \\
\hline El-Remelah & 11.130 & 4.830 & 2.313 & 3.002 & 2.799 & 4.815 \\
\hline Alam El-Roum & 11.527 & 2.380 & 2.367 & 4.226 & 5.495 & 5.199 \\
\hline Mena-Hashish & 2.870 & 3.337 & 2.102 & 3.695 & 3.213 & 3.043 \\
\hline El-Fayroz & 4.783 & 11.597 & 3.213 & 6.683 & 15.260 & 8.307 \\
\hline Romel & 2.660 & 4.433 & 3.006 & 3.965 & 8.658 & 4.544 \\
\hline El-Boseet & 3.547 & 3.150 & 2.205 & 4.662 & 3.569 & 3.427 \\
\hline Cleopatra & 7.653 & 3.733 & 3.609 & 5.504 & 6.836 & 5.467 \\
\hline El-Gharam & 2.380 & 10.383 & 2.318 & 5.081 & 4.064 & 4.845 \\
\hline El-Obayed & 4.923 & 148.050 & 2.552 & 85.581 & 5.882 & 49.398 \\
\hline Ageba & 3.663 & 4.830 & 1.701 & 6.260 & 3.681 & 4.027 \\
\hline Min & 2.380 & 2.380 & 1.701 & 3.002 & 2.799 & 3.043 \\
\hline $\operatorname{Max}$ & 11.527 & 148.050 & 3.609 & 85.581 & 15.260 & 49.398 \\
\hline Average & 5.514 & 19.672 & 2.539 & 12.866 & 5.946 & 9.307 \\
\hline \multicolumn{7}{|c|}{ Lead $(\mu \mathrm{g} / \mathrm{L})$} \\
\hline El-Remelah & 16.590 & 8.633 & 8.588 & 10.907 & 15.675 & 12.079 \\
\hline Alam El-Roum & 21.070 & 7.303 & 8.675 & 12.024 & 11.159 & 12.046 \\
\hline Mena-Hashish & 6.463 & 13.440 & 8.244 & 9.717 & 13.019 & 10.177 \\
\hline El-Fayroz & 43.610 & 11.620 & 19.953 & 46.806 & 65.579 & 37.514 \\
\hline Romel & 6.977 & 17.920 & 12.842 & 20.870 & 42.032 & 20.128 \\
\hline El-Boseet & 6.977 & 7.793 & 15.372 & 12.362 & 31.931 & 14.887 \\
\hline Cleopatra & 6.790 & 16.753 & 10.392 & 13.398 & 38.945 & 17.256 \\
\hline El-Gharam & 7.303 & 7.957 & 12.281 & 7.901 & 28.158 & 12.720 \\
\hline El-Obayed & 7.957 & 9.287 & 37.616 & 31.527 & 23.087 & 21.895 \\
\hline Ageba & 7.793 & 8.120 & 9.189 & 9.387 & 7.616 & 8.421 \\
\hline Min & 6.463 & 7.303 & 8.244 & 7.901 & 7.616 & 8.421 \\
\hline Max & 43.610 & 17.920 & 37.616 & 46.806 & 65.579 & 37.514 \\
\hline Average & 13.153 & 10.883 & 14.315 & 17.490 & 27.720 & 16.712 \\
\hline
\end{tabular}


Table 5. Distribution of $\mathrm{Ni}, \mathrm{Zn}$ and $\mathrm{Fe}(\mu \mathrm{g} / \mathrm{L})$ concentrations in different water samples collected from Marsa-Matrouh beaches during 2010-2011.

\begin{tabular}{|c|c|c|c|c|c|c|}
\hline \multirow{2}{*}{ Station } & \multicolumn{2}{|c|}{2010} & \multicolumn{3}{|c|}{2011} & \multirow{2}{*}{$\begin{array}{l}\text { Annual } \\
\text { Average }\end{array}$} \\
\hline & Summer & Autumn & Winter & Spring & Summer & \\
\hline \multicolumn{7}{|c|}{ Nickel $(\mu \mathrm{g} / \mathrm{L})$} \\
\hline El-Remelah & 1.423 & 3.057 & 2.117 & 2.134 & 2.607 & 2.273 \\
\hline Alam El-Roum & 1.913 & 1.307 & 2.126 & 2.182 & 3.194 & 2.144 \\
\hline Mena-Hashish & 19.903 & 1.773 & 1.389 & 2.369 & 1.422 & 5.371 \\
\hline El-Fayroz & 2.263 & 1.237 & 3.006 & 3.811 & 3.925 & 2.848 \\
\hline Romel & 1.703 & 1.213 & 2.382 & 3.212 & 3.978 & 2.498 \\
\hline El-Boseet & 1.26 & 1.727 & 1.623 & 2.222 & 3.339 & 2.034 \\
\hline Cleopatra & 2.123 & 1.633 & 2.05 & 3.033 & 2.351 & 2.238 \\
\hline El-Gharam & 0.84 & 1.12 & 3.025 & 4.229 & 2.391 & 2.321 \\
\hline El-Obayed & 1.307 & 1.353 & 2.905 & 6.069 & 2.213 & 2.769 \\
\hline Ageba & 1.423 & 1.143 & 2.899 & 2.279 & 1.881 & 1.925 \\
\hline Min & 0.840 & 1.120 & 1.389 & 2.134 & 1.422 & 1.925 \\
\hline $\operatorname{Max}$ & 19.903 & 3.057 & 3.025 & 6.069 & 3.978 & 5.371 \\
\hline Average & 3.416 & 1.556 & 2.352 & 3.154 & 2.730 & 2.642 \\
\hline \multicolumn{7}{|c|}{$\operatorname{Zinc}(\mu \mathrm{g} / \mathrm{L})$} \\
\hline El-Remelah & 12.273 & 30.473 & 22.935 & 36.405 & 32.408 & 26.899 \\
\hline Alam El-Roum & 38.103 & 31.313 & 11.64 & 38.865 & 57.18 & 35.420 \\
\hline Mena-Hashish & 4.48 & 25.993 & 16.643 & 28.305 & 23.558 & 19.796 \\
\hline El-Fayroz & 12.25 & 22.003 & 50.708 & 42.135 & 35.79 & 32.577 \\
\hline Romel & 14.14 & 22.05 & 37.815 & 48.803 & 43.103 & 33.182 \\
\hline El-Boseet & 11.993 & 28.07 & 17.94 & 28.208 & 24.69 & 22.180 \\
\hline Cleopatra & 13.3 & 252.957 & 33.548 & 36.285 & 23.243 & 71.867 \\
\hline El-Gharam & 20.603 & 20.557 & 34.89 & 18.698 & 20.423 & 23.034 \\
\hline El-Obayed & 6.393 & 31.36 & 32.843 & 35.22 & 25.118 & 26.187 \\
\hline Ageba & 15.493 & 10.337 & 38.098 & 25.118 & 13.658 & 20.541 \\
\hline Min & 4.480 & 10.337 & 11.640 & 18.698 & 13.658 & 19.796 \\
\hline Max & 38.103 & 252.957 & 50.708 & 48.803 & 57.180 & 71.867 \\
\hline Average & 14.903 & 47.511 & 29.706 & 33.804 & 29.917 & 31.168 \\
\hline \multicolumn{7}{|c|}{ Iron $(\mu \mathrm{g} / \mathrm{L})$} \\
\hline El-Remelah & 132.533 & 15.167 & 71.805 & 45.108 & 79.008 & 68.724 \\
\hline Alam El-Roum & 62.3 & 22.4 & 83.226 & 42.453 & 85.506 & 59.177 \\
\hline Mena-Hashish & 50.867 & 97.067 & 42.126 & 64.278 & 31.098 & 57.087 \\
\hline El-Fayroz & 132.3 & 32.9 & 75.765 & 74.709 & 76.842 & 78.503 \\
\hline Romel & 77 & 112.7 & 65.076 & 70.053 & 103.503 & 85.666 \\
\hline El-Boseet & 90.3 & 22.867 & 45.327 & 54.048 & 104.979 & 63.504 \\
\hline Cleopatra & 49 & 136.5 & 54.456 & 80.515 & 45.582 & 73.211 \\
\hline El-Gharam & 36.867 & 22.4 & 101.196 & 158.445 & 66.531 & 77.088 \\
\hline El-Obayed & 27.3 & 52.733 & 71.805 & 120.474 & 56.421 & 65.747 \\
\hline Ageba & 51.567 & 27.3 & 95.775 & 61.44 & 68.834 & 60.983 \\
\hline Min & 27.300 & 15.167 & 42.126 & 42.453 & 31.098 & 57.087 \\
\hline Max & 132.533 & 136.500 & 101.196 & 158.445 & 104.979 & 85.666 \\
\hline Average & 71.003 & 54.203 & 70.656 & 77.152 & 71.830 & 68.969 \\
\hline
\end{tabular}


The dissolved nickel concentrations along Marsa-Matrouh beaches ranged between 0.840 and $19.903 \mu \mathrm{g} / \mathrm{l}$ determined at El-Gharam and Mena-Hashish stations during summer 2010, respectively. The annual average concentration of $\mathrm{Ni}$ in the investigated beaches was $2.642 \pm 1.004 \mu \mathrm{g} / \mathrm{l}$ which is higher than that of natural sea water $(0.5 \mu \mathrm{g} / \mathrm{l})$ according to [49], but it was still lower than the permissible limits $(25-150 \mu \mathrm{g} / \mathrm{l})$ recorded for Canadian acceptable limits [53]. The highest level was recorded during summer 2010 followed by spring and summer 2011, may be attributed to the phytoplankton pollution occurring in spring and summer seasons.

The annual average concentration of dissolved lead in the investigated area was $16.712 \pm 8.469 \mu \mathrm{g} / \mathrm{l}$ which ranged from 6.463 and $65.579 \mu \mathrm{g} / \mathrm{l}$ recorded at Mena-Hashish and El-Fayroz stations during summer 2010 and 2011, respectively. Based on the annual average concentration of lead, it is higher than that of natural sea water concentration $(0.03 \mu \mathrm{g} / \mathrm{l})$ according to Fifield and Haines (2000) but it still lower than acceptable limits $(100 \mu \mathrm{g} / \mathrm{l})$ according to the Russian limits [50] of heavy metals. The higher average level of $\mathrm{Pb}$ was recorded during summer 2011 while the lowest value was observed during autumn 2010.

Zinc may occur in natural sea water at level reaches to $10 \mu \mathrm{g} / 1$ [49]. The concentration of zinc in the investigated area ranged between 4.480 and $252.957 \mu \mathrm{g} / \mathrm{l}$ determined at Mena-Hashish and Cleopatra during summer and autumn2010, respectively. The annual average concentration was $31.168 \pm 15.322 \mu \mathrm{g} / \mathrm{l}$ which is lower than the [50] (30 - $2000 \mu \mathrm{g} / \mathrm{l})$. The odd record of $\mathrm{Zn}$ concentration in Cleopatra station during autumn $2010(252.957 \mu \mathrm{g} / \mathrm{l})$ reflect an unmoral case and there is an external source of pollution in this station. The highest average concentration was recorded during autumn 2010 followed by spring 2010 while the lowest value was investigated during summer 2010. The low levels recorded during summer 2010 and 2011 may be attributed to high precipitation process of zinc salt from water column to sediment due the high temperature in summer season. The relatively high concentrations of $\mathrm{Zn}$ in cold seasons (winter and autumn) were reported by the low adsorption of $\mathrm{Zn}$ with temperature decreasing [54].

Generally, it was observed that, all studied beaches are not polluted with heavy metal and the reported concentrations of the investigated heavy metals are still far away below the acceptable international limits except for some stations which are polluted with $\mathrm{Cu}$ and $\mathrm{Cd}$ such as Cleopatra and El-Obayed stations.

\subsubsection{Heavy Metal Pollution Index}

In computing the HPI for the present study, the mean concentration values of the selected metals $(\mathrm{Pb}, \mathrm{Cd}, \mathrm{Zn}, \mathrm{Cu}, \mathrm{Ni}$ and $\mathrm{Fe}$ ) have been taken into account. The value of Heavy Metal Pollution Index (HPI) was to be found in the range from 7.11 to 79.55 . The highest value of HPI was found for water samples collected from Cleopatra Beach followed by El-Obeyad Beach (53.83) while the lower value was detected for Ageba Beach. The higher values of HPI may be attributed to sewage dumping into these areas. The HPI values of the samples 
within study area are found below the critical pollution index (100), above which the overall pollution level should be considered unacceptable [27] [28] [29]. This indicates the water is not critically polluted with respect to the investigated heavy metals (Figure 2). However, Cleopatra station is not very far from the critically pollution index value (79.55) (100).

\subsubsection{Statistical Analysis}

By applying the Spearman (non-parametric) rank order correlations, the results revealed that the dissolved form of $\mathrm{Cu}$ is correlated with both dissolved forms of lead and $\mathrm{Zn}$ (0.624 and 0.588 respectively). Furthermore, there is a good correlation between the dissolved form of $\mathrm{Zn}$ with the dissolved forms of $\mathrm{Cd}, \mathrm{Pb}$ and $\mathrm{Fe}$ (0.822, 0.745 and 0.576 respectively) as showed by Table 6 . This result revealed that these metals have the same source of contamination.

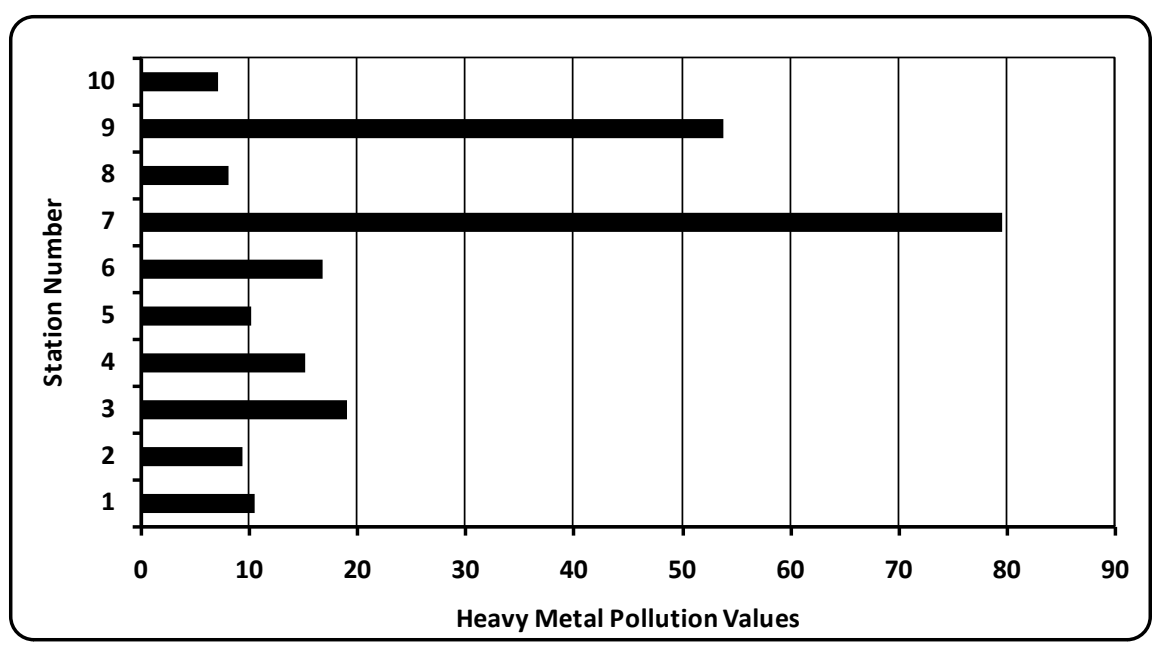

Figure 2. Percentage of heavy metal pollution index in water samples.

Table 6. Correlation in water and in sediment.

\begin{tabular}{|c|c|c|c|c|c|c|c|}
\hline & Metal & $\mathrm{Cd}$ & $\mathrm{Cu}$ & $\mathrm{Pb}$ & $\mathrm{Ni}$ & $\mathrm{Zn}$ & $\mathrm{Fe}$ \\
\hline \multirow{6}{*}{ Water } & $\mathrm{Cd}$ & 1 & & & & & \\
\hline & $\mathrm{Cu}$ & 0.176 & 1 & & & & \\
\hline & $\mathrm{Pb}$ & 0.345 & $0.624^{*}$ & 1 & & & \\
\hline & $\mathrm{Ni}$ & 0.285 & 0.248 & 0.200 & 1 & & \\
\hline & $\mathrm{Zn}$ & 0.152 & $0.588^{*}$ & $0.745^{\star}$ & 0.454 & 1 & \\
\hline & $\mathrm{Fe}$ & 0.042 & 0.321 & 0.321 & 0.430 & $0.576^{*}$ & 1 \\
\hline \multirow{6}{*}{ Sediment } & $\mathrm{Cd}$ & 1 & & & & & \\
\hline & $\mathrm{Cu}$ & -0.104 & 1 & & & & \\
\hline & $\mathrm{Pb}$ & -0.205 & $0.878^{\star *}$ & 1 & & & \\
\hline & $\mathrm{Ni}$ & -0.229 & 0.515 & 0.310 & 1 & & \\
\hline & $\mathrm{Zn}$ & -0.521 & $0.634^{\star}$ & $-0.768^{\star *}$ & 0.406 & 1 & \\
\hline & $\mathrm{Fe}$ & -0.388 & $0.806^{* *}$ & $0.644^{*}$ & $0.635^{*}$ & 0.5210 & 1 \\
\hline
\end{tabular}

Note: ${ }^{*}$ Correlation is significant at the 0.05 level; ${ }^{* *}$ Correlation is significant at the 0.01 level. 
1) Principal component analysis

Multivariate analysis (Principal component analysis, PCA) has been applied on the data set for ten water samples and six variables $(\mathrm{Cd}, \mathrm{Cu}, \mathrm{Pb}, \mathrm{Ni}, \mathrm{Zn}$ and $\mathrm{Fe}$ ). R-mode factor analysis with VARIMAX rotation with Kaiser Normalization, as well as the Eigen values was applied to the previous inorganic pollutants in the sediment samples. The PCA results of water data set are presented in Table 7. PC1, PC2 and PC3 account for 37.202, 23.082 and $16.975 \%$ of the total variance, respectively. $\mathrm{PC} 1$ has high loadings of $\mathrm{Cd}, \mathrm{Zn}$ and moderate loading of Fe. PC2 is loaded on $\mathrm{Cu}$ and $\mathrm{Pb}$. PC3 is loaded on Ni only.

2) Cluster analysis

By applying, the cluster analysis for both the complete and centroid linkages. Similar relations between pollutants were obtained by the two studied clustering methods. The resultant dendrograms confirm the results obtained with PCA. Indeed, there were five clusters, which can be identified as follows: the first cluster (A) contains ( $\mathrm{Cd}$ and $\mathrm{Zn}$ ) at distance 1 (which was well correlated in Factor 1 in PCA); at a higher distance (about 14) Fe is fused with cluster (A) formed cluster $(\mathrm{C})$ (which is also correlated in Factor 1 but with moderate value). The second cluster $(\mathrm{B})$ contains $(\mathrm{Cu}$ and $\mathrm{Pb}$ ) at distance 10 (which was well correlated in Factor 2 in PCA). At distance 22, Ni is fused with cluster (B) forming cluster (D) (which appear at Factor 3 alone) as illustrated by Figure 3. At distance 25 the two clusters (C and D) are fused forming the cluster (E).

\subsection{Sediment}

The distribution of investigated metals $(\mathrm{Cd}, \mathrm{Cu}, \mathrm{Ni}, \mathrm{Pb}$, and $\mathrm{Zn}$ ) along MarsaMatrouh Beaches (summer 2010 spring 2011) were reported in Table 8 and Table 9.

The highest average concentration of Cd was noticed in autumn 2010 (1.235 \pm $0.720 \mu \mathrm{g} / \mathrm{g})$ followed by spring $2011(0.754 \pm 0.208 \mu \mathrm{g} / \mathrm{g})$, while winter $2011 \mathrm{rec}$ orded the lowest average value for Cd $(0.473 \pm 0.501 \mu \mathrm{g} / \mathrm{g})$. On the other hand, Agiba station recorded the highest values of Cd during summer and autumn 2010 ( 1.015 and $2.628 \mu \mathrm{g} / \mathrm{g}$ respectively) while Romel station recorded the highest Cd values during both winter and spring 2010 (1.841 and $1.115 \mu \mathrm{g} / \mathrm{g}$ respectively). The lowest value of $\mathrm{Cd}$ was detected at El-Gharam station during winter $2011(0.164 \mu \mathrm{g} / \mathrm{g})$.

The average concentrations of copper during the four seasons were decreased in the order: summer $2010(5.976 \pm 3.261 \mu \mathrm{g} / \mathrm{g})>$ spring $2011(5.256 \pm 1.546$ $\mu \mathrm{g} / \mathrm{g})>$ autumn $2010(4.482 \pm 0.727 \mu \mathrm{g} / \mathrm{g})>$ winter $2011(3.852 \pm 0.574 \mu \mathrm{g} / \mathrm{g})$. The lowest value of copper was observed at Cleopatra station during summer

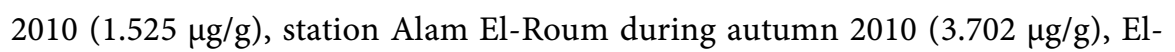
Obayed station during winter $2010(3.196 \mu \mathrm{g} / \mathrm{g})$ and both stations El-Obayed and Mena-Hashish during spring 2011 (3.812 and $3.817 \mu \mathrm{g} / \mathrm{g}$ respectively). On the other hand the highest values of $\mathrm{Cu}$ were recorded at El-Fayroz station during both summer 2010 and winter 2011 (11.937 and $4.928 \mu \mathrm{g} / \mathrm{g}$ respectively) and at Romel station during both autumn 2010 and spring 2011 (6.234 and 4.928 $\mu \mathrm{g} / \mathrm{g}$ respectively). 
Table 7. VARIMAX normalization rotated factor loading for three factors obtained according to pollutants in the water samples along Matrouh Beaches.

\begin{tabular}{cccc}
\hline Variable & Factor 1 & Factor 2 & Factor 3 \\
\hline $\mathrm{Cd}$ & $\mathbf{0 . 8 7 7}$ & -0.124 & 0.437 \\
$\mathrm{Cu}$ & 0.400 & $\mathbf{0 . 7 4 6}$ & 0.317 \\
$\mathrm{~Pb}$ & 0.424 & $\mathbf{0 . 6 8 2}$ & -0.466 \\
$\mathrm{Ni}$ & -0.164 & 0.300 & $\mathbf{0 . 5 5 6}$ \\
$\mathrm{Zn}$ & $\mathbf{0 . 8 3 4}$ & -0.507 & 0.071 \\
$\mathrm{Fe}$ & $\mathbf{0 . 6 3 4}$ & -0.011 & -0.443 \\
Variance \% & 37.202 & 23.082 & 16.975 \\
Cumulative \% & 37.202 & 60.284 & 77.259 \\
\hline
\end{tabular}

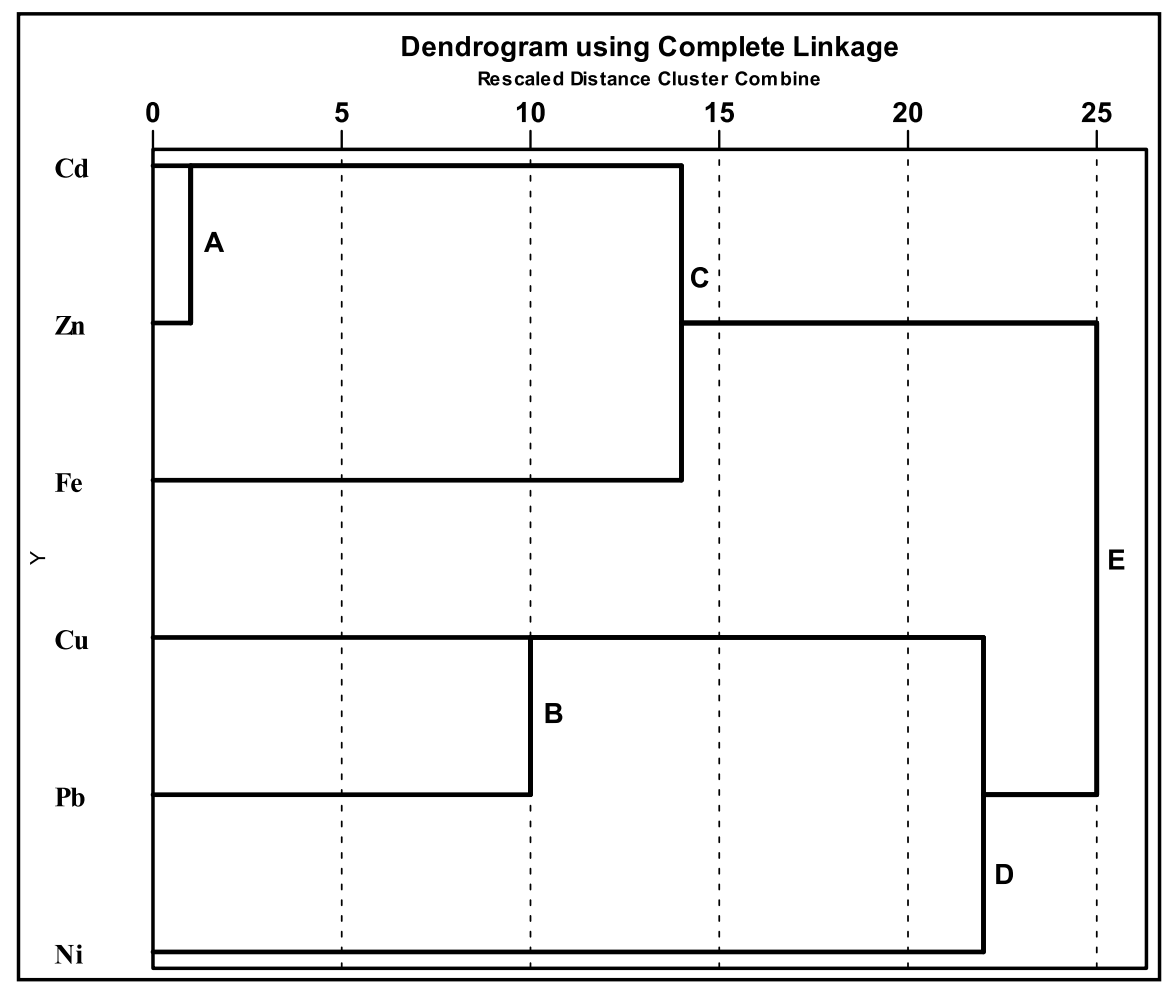

Figure 3. Dendogram obtained by hierarchical clustering analysis for metals in water samples.

The highest average concentration of iron was detected at summer 2010 $(3886.404 \pm 6946.007 \mu \mathrm{g} / \mathrm{g})$ followed by autumn $2010(474.277 \pm 152.904 \mu \mathrm{g} / \mathrm{g})$ while the lowest concentration was noted in spring 2011 (361.189 \pm 204.498 $\mu \mathrm{g} / \mathrm{g})$. The highest value of iron was observed at Cleopatra station during summer 2010 (21260.351 $\mu \mathrm{g} / \mathrm{g})$, Alam El-Roum station during autumn 2010 (770.874 $\mu \mathrm{g} / \mathrm{g}$ ), El-Remelah station during both winter and spring 2011 (696.694 and $789.596 \mu \mathrm{g} / \mathrm{g}$ respectively). The lowest concentration of iron was detected at Agiba station during summer $2010(99.859 \mu \mathrm{g} / \mathrm{g})$, El-Gharam station during autumn $2010(306.179 \mu \mathrm{g} / \mathrm{g})$, El-Obayed station during winter $2011(243.041 \mu \mathrm{g} / \mathrm{g})$, and at Alam El-Roum station during spring $2011(145.134 \mu \mathrm{g} / \mathrm{g})$. 
Table 8. Distribution of $\mathrm{Cd}, \mathrm{Cu}$ and $\mathrm{Pb}(\mu \mathrm{g} / \mathrm{L})$ concentrations in different sediment samples collected from Marsa-Matrouh beaches during 2010-2011.

\begin{tabular}{|c|c|c|c|c|c|}
\hline \multirow{2}{*}{ Location } & \multicolumn{2}{|c|}{2010} & \multicolumn{2}{|c|}{2011} & \multirow{2}{*}{$\begin{array}{l}\text { Annual } \\
\text { Average }\end{array}$} \\
\hline & Summer & Autumn & Winter & Spring & \\
\hline \multicolumn{6}{|c|}{ Cadmium ( $\mu \mathrm{g} / \mathrm{g} \mathrm{dw})$} \\
\hline El-Remelah & 0.311 & 1.238 & 0.500 & 0.549 & 0.649 \\
\hline Alam El-Roum & 0.484 & 0.805 & 0.335 & 0.905 & 0.632 \\
\hline Mena-Hashish & 0.517 & 0.868 & 0.601 & 0.716 & 0.676 \\
\hline El-Fayroz & 0.417 & 0.629 & 0.277 & 0.514 & 0.459 \\
\hline Romel & 0.433 & 0.777 & 1.841 & 1.115 & 1.042 \\
\hline El-Boseet & 0.485 & 0.654 & 0.176 & 0.641 & 0.489 \\
\hline Cleopatra & 0.604 & 0.833 & 0.347 & 0.854 & 0.659 \\
\hline El-Gharam & 0.799 & 1.592 & 0.164 & 0.505 & 0.765 \\
\hline El-Obayed & 0.521 & 2.329 & 0.192 & 0.982 & 1.006 \\
\hline Ageba & 1.015 & 2.628 & 0.293 & 0.754 & 1.173 \\
\hline Min & 0.311 & 0.629 & 0.164 & 0.505 & 0.459 \\
\hline $\operatorname{Max}$ & 1.015 & 2.628 & 1.841 & 1.115 & 1.173 \\
\hline Average & 0.559 & 1.235 & 0.473 & 0.754 & 0.755 \\
\hline \multicolumn{6}{|c|}{ Copper $(\mu g / g d w)$} \\
\hline El-Remelah & 4.472 & 4.326 & 3.823 & 5.998 & 4.655 \\
\hline Alam El-Roum & 6.355 & 3.702 & 3.627 & 4.095 & 4.445 \\
\hline Mena-Hashish & 3.546 & 4.811 & 3.907 & 3.817 & 4.020 \\
\hline El-Fayroz & 11.937 & 4.463 & 11.000 & 5.521 & 8.230 \\
\hline Romel & 9.862 & 6.234 & 4.603 & 8.977 & 7.419 \\
\hline El-Boseet & 6.492 & 3.800 & 3.806 & 5.404 & 4.876 \\
\hline Cleopatra & 1.525 & 8.800 & 8.000 & 9.000 & 6.831 \\
\hline El-Gharam & 3.480 & 4.800 & 3.276 & 4.139 & 3.924 \\
\hline El-Obayed & 3.759 & 4.450 & 3.196 & 3.812 & 3.804 \\
\hline Ageba & 8.335 & 4.360 & 3.253 & 5.738 & 5.422 \\
\hline Min & 1.525 & 3.702 & 3.196 & 3.812 & 3.804 \\
\hline $\operatorname{Max}$ & 11.937 & 8.800 & 11.000 & 9.000 & 8.230 \\
\hline Average & 5.976 & 4.975 & 4.849 & 5.650 & 5.363 \\
\hline \multicolumn{6}{|c|}{ Lead $(\mu g / g d w)$} \\
\hline El-Remelah & 13.713 & 17.029 & 3.517 & 12.858 & 11.779 \\
\hline Alam El-Roum & 21.216 & 13.017 & 5.853 & 7.651 & 11.934 \\
\hline Mena-Hashish & 13.685 & 13.321 & 5.170 & 8.318 & 10.124 \\
\hline El-Fayroz & 14.152 & 33.363 & 19.909 & 22.593 & 22.504 \\
\hline Romel & 29.754 & 15.799 & 18.820 & 19.554 & 20.982 \\
\hline El-Boseet & 21.935 & 23.930 & 9.642 & 13.051 & 17.140 \\
\hline Cleopatra & 22.369 & 24.233 & 15.371 & 9.710 & 17.921 \\
\hline El-Gharam & 27.868 & 4.000 & 3.875 & 27.904 & 15.912 \\
\hline El-Obayed & 18.203 & 4.189 & 6.213 & 10.714 & 9.830 \\
\hline Ageba & 16.903 & 10.158 & 11.943 & 16.897 & 13.975 \\
\hline Min & 13.685 & 4.000 & 3.517 & 7.651 & 9.830 \\
\hline Max & 29.754 & 33.363 & 19.909 & 27.904 & 22.504 \\
\hline Average & 19.980 & 15.904 & 10.031 & 14.925 & 15.210 \\
\hline
\end{tabular}


Table 9. Distribution of $\mathrm{Ni}, \mathrm{Zn}$ and $\mathrm{Fe}(\mu \mathrm{g} / \mathrm{L})$ concentrations in different sediment samples collected from Marsa-Matrouh beaches during 2010-2011.

\begin{tabular}{|c|c|c|c|c|c|}
\hline \multirow{2}{*}{ Location } & \multicolumn{2}{|c|}{2010} & \multicolumn{2}{|c|}{2011} & \multirow{2}{*}{$\begin{array}{l}\text { Annual } \\
\text { Average }\end{array}$} \\
\hline & Summer & Autumn & Winter & Spring & \\
\hline \multicolumn{6}{|c|}{ Nickel $(\mu \mathrm{g} / \mathrm{g} \mathrm{dw})$} \\
\hline El-Remelah & 1.231 & 3.67 & 2.348 & 2.416 & 2.416 \\
\hline Alam El-Roum & 2.452 & 2.347 & 2.300 & 2.366 & 2.366 \\
\hline Mena-Hashish & 16.66 & 2.846 & 2.804 & 7.437 & 7.437 \\
\hline El-Fayroz & 7.815 & 4.926 & 4.668 & 5.803 & 5.803 \\
\hline Romel & 6.023 & 3.009 & 4.328 & 4.453 & 4.453 \\
\hline El-Boseet & 2.251 & 3.049 & 2.540 & 2.613 & 2.613 \\
\hline Cleopatra & 16.905 & 2.412 & 2.777 & 7.365 & 7.365 \\
\hline El-Gharam & 2.448 & 1.775 & 2.024 & 2.082 & 2.082 \\
\hline El-Obayed & 2.625 & 0.91 & 1.694 & 1.743 & 1.743 \\
\hline Ageba & 3.35 & 3.623 & 3.341 & 3.438 & 3.438 \\
\hline Min & 1.231 & 0.910 & 1.694 & 1.743 & 1.743 \\
\hline Max & 16.905 & 4.926 & 4.668 & 7.437 & 7.437 \\
\hline Average & 6.176 & 2.857 & 2.882 & 3.972 & 3.972 \\
\hline \multicolumn{6}{|c|}{ Zinc $(\mu \mathrm{g} / \mathrm{g} d \mathrm{w})$} \\
\hline El-Remelah & 13.110 & 16.031 & 19.469 & 32.888 & 20.375 \\
\hline Alam El-Roum & 15.951 & 14.119 & 13.252 & 28.237 & 17.890 \\
\hline Mena-Hashish & 12.288 & 21.808 & 22.120 & 35.088 & 22.826 \\
\hline El-Fayroz & 44.301 & 44.073 & 12.598 & 31.200 & 33.043 \\
\hline Romel & 42.330 & 19.423 & 21.707 & 40.501 & 30.990 \\
\hline El-Boseet & 22.914 & 24.668 & 12.354 & 91.598 & 37.884 \\
\hline Cleopatra & 61.339 & 31.811 & 10.611 & 16.025 & 29.947 \\
\hline El-Gharam & 11.993 & 18.423 & 10.974 & 38.939 & 20.082 \\
\hline El-Obayed & 13.804 & 23.365 & 12.048 & 15.241 & 16.115 \\
\hline Ageba & 16.228 & 18.696 & 15.939 & 16.845 & 16.927 \\
\hline Min & 11.993 & 14.119 & 10.611 & 15.241 & 16.115 \\
\hline $\operatorname{Max}$ & 61.339 & 44.073 & 22.120 & 91.598 & 37.884 \\
\hline Average & 25.426 & 23.242 & 15.107 & 34.656 & 24.608 \\
\hline \multicolumn{6}{|c|}{ Iron $(\mu \mathrm{g} / \mathrm{g} \mathrm{dw})$} \\
\hline El-Remelah & 1731.956 & 650.486 & 696.694 & 789.596 & 967.183 \\
\hline Alam El-Roum & 591.729 & 770.874 & 453.669 & 145.134 & 490.352 \\
\hline Mena-Hashish & 380.22 & 451.78 & 315.330 & 244.21 & 347.885 \\
\hline El-Fayroz & 9018.639 & 426.673 & 397.551 & 365.981 & 2552.211 \\
\hline Romel & 2819.793 & 460.001 & 426.372 & 419.115 & 1031.320 \\
\hline El-Boseet & 551.939 & 392.369 & 371.593 & 402.411 & 429.578 \\
\hline Cleopatra & 10260.351 & 603.325 & 546.361 & 235.757 & 2911.448 \\
\hline El-Gharam & 266.114 & 306.179 & 274.466 & 217.22 & 265.995 \\
\hline El-Obayed & 143.444 & 363.229 & 243.041 & 185.895 & 233.902 \\
\hline Ageba & 99.859 & 317.851 & 541.473 & 606.568 & 391.438 \\
\hline Min & 99.859 & 306.179 & 243.041 & 145.134 & 198.553 \\
\hline Max & 10260.351 & 770.874 & 696.694 & 789.596 & 2911.448 \\
\hline Average & 2586.404 & 474.277 & 426.655 & 361.189 & 962.131 \\
\hline
\end{tabular}


Stations Mena-Hashish and Cleopatra recorded the highest values of $\mathrm{Ni}$ in summer 2010 (16.660 and $16.905 \mu \mathrm{g} / \mathrm{g}$ respectively) and spring 2011 (7.437 and $7.365 \mu \mathrm{g} / \mathrm{l}$ respectively). El-Fayroz station recorded the highest values during autumn 2010 and winter 2011 (4.926, $4.668 \mu \mathrm{g} / \mathrm{g}$ respectively). On the other hand, El-Obayed station recorded the lowest values of Ni during autumn 2010, winter and spring $2011(0.910,1.694,1.743 \mu \mathrm{g} / \mathrm{g}$ respectively) while El-Remelah station recorded the lowest value during summer $2010(1.231 \mu \mathrm{g} / \mathrm{g})$. The highest mean value of nickel was detected during summer $2010(6.176 \pm 5.925 \mu \mathrm{g} / \mathrm{g})$ while the lowest ones were recorded during winter $2011(2.882 \pm 0.966 \mu \mathrm{g} / \mathrm{g})$ and autumn $2010(2.857 \pm 1.106 \mu \mathrm{g} / \mathrm{g})$.

The average concentration of lead decreased in the order autumn 2010 (23.814 $\pm 10.654 \mu \mathrm{g} / \mathrm{g})>$ summer $2010(19.980 \pm 5.718 \mu \mathrm{g} / \mathrm{g})>\operatorname{spring} 2011(13.925 \pm$ $6.133 \mu \mathrm{g} / \mathrm{g})>$ winter $2011(9.031 \pm 5.116 \mu \mathrm{g} / \mathrm{g})$. The lowest value of $\mathrm{Pb}$ was observed at El-Remelah station during winter $2011(3.517 \mu \mathrm{g} / \mathrm{g})$ while its highest value was detected at El-Obayed station during autumn 2010 (44.189 $\mu \mathrm{g} / \mathrm{g})$. Romel station recorded the highest values of $\mathrm{Pb}$ during summer 2010 and winter 2011 (29.754 and $18.820 \mu \mathrm{g} / \mathrm{g}$ respectively) while El-Gharam station 8 recorded the higher value during spring $2011(27.904 \mu \mathrm{g} / \mathrm{g})$. The lower values of $\mathrm{Pb}$ were recorded at Mmena-Hashish during summer 2010 (13.685 $\mu \mathrm{g} / \mathrm{g})$, at Alam-ElRoum and Mena-Hashish during autumn (13.017 and $13.321 \mu \mathrm{g} / \mathrm{g}$ respectively) and at Alam El-Roum during spring $2011(7.651 \mu \mathrm{g} / \mathrm{g})$.

The highest average concentration of zinc during the period of study was observed during spring $2011(34.656 \pm 22.092 \mu \mathrm{g} / \mathrm{g})$ followed by summer 2010 $(25.426 \pm 8.852 \mu \mathrm{g} / \mathrm{g})$ while the lowest was detected in winter $2011(15.107 \pm$ $4.428 \mu \mathrm{g} / \mathrm{g})$. During summer the highest value was detected at Cleopatra station $(61.339 \mu \mathrm{g} / \mathrm{g})$, during autumn the highest value was observed at El-Fayroz station $(44.073 \mu \mathrm{g} / \mathrm{g})$, during winter the highest value was recorded at Mena-Hashish station $(22.120 \mu \mathrm{g} / \mathrm{g})$ but during spring the highest value was noted at ElBoseet station $(91.598 \mu \mathrm{g} / \mathrm{g})$. The lowest values of $\mathrm{Zn}$ were recorded at El-Gharam station during summer $2010(11.993 \mu \mathrm{g} / \mathrm{g})$, at Alam El-Roum station during autumn 2010 (14.119), Cleopatra and El-Gharam stations during winter 2011 (10.611 and $10.974 \mu \mathrm{g} / \mathrm{g}$ respectively), and El-Obayed station during spring 2011 $(15.241 \mu \mathrm{g} / \mathrm{g})$.

\subsubsection{Assessment of Metal Contaminatio}

1) Sediment quality guidelines (SQGs)

By comparison the present data by the different available SQGs, the concentrations of $\mathrm{Cu}, \mathrm{Ni}, \mathrm{Pb}$ and $\mathrm{Zn}$ in the four investigated seasons (summer 2010spring 2011) are lower than the threshold effect concentrations revealing that there is no toxic adverse effect on the sediment-dwelling organisms along Marsa-Matrouh beaches. On the other hand, the concentration of $\mathrm{Cd}$ exceeding the threshold effect concentrations in $20 \%, 60 \%, 10 \%$ and $50 \%$ of investigated stations in summer 2010, autumn 2010, winter 2011 and spring 2011 respectively but still lower than the probable effect concentrations. This result revealed that 
the toxic adverse effect on the sediment-dwelling organisms from Cd may be fluctuated from $20 \%$ to $50 \%$.

2) Hazard quotient

Calculated hazard quotient (HQs) for the $\mathrm{Cd}, \mathrm{Cu}, \mathrm{Ni}, \mathrm{Pb}$ and $\mathrm{Zn}$ in the investigated sediments are shown in Figures 4-8. Based on the calculated values of PEC HQ, it can be recognized that all investigated metals had values lower than one. Thus it can be concluded that no frequent toxic adverse ecological effects are expected to occur with respect to these metals. TEC HQ calculated for all the investigated trace metals were lower than 1 except for Cd which showing higher value than 1, indicating the possibility of occurrence of toxic adverse ecological effects to benthic organisms from $\mathrm{Cd}$. On the other hand, rare toxic adverse ecological effects are expected to occur with respect to $\mathrm{Cu}, \mathrm{Ni}, \mathrm{Pb}$ and $\mathrm{Zn}$. These results were in agreement with the Sediment quality guidelines calculations.

3) Geoaccumulation index

By apply Muller equation on the annual average concentration for all stations uder investigation, the sample percentages according to Müller's classes [41],

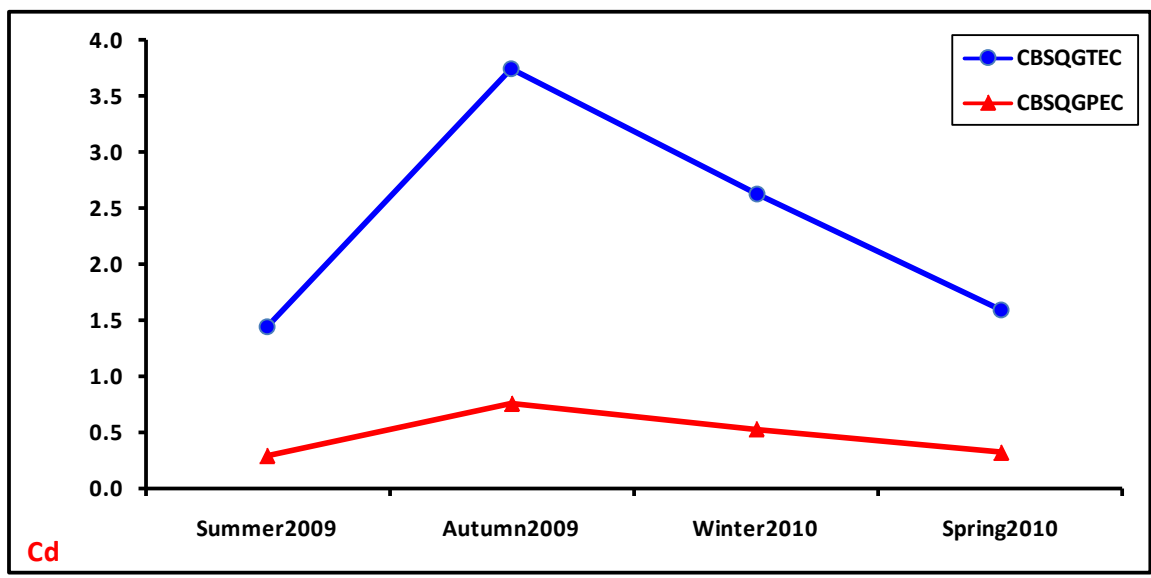

Figure 4. CBSQTEC and CBSQPEC for Cd in sediment samples collected from MarsaMatrouh beaches.

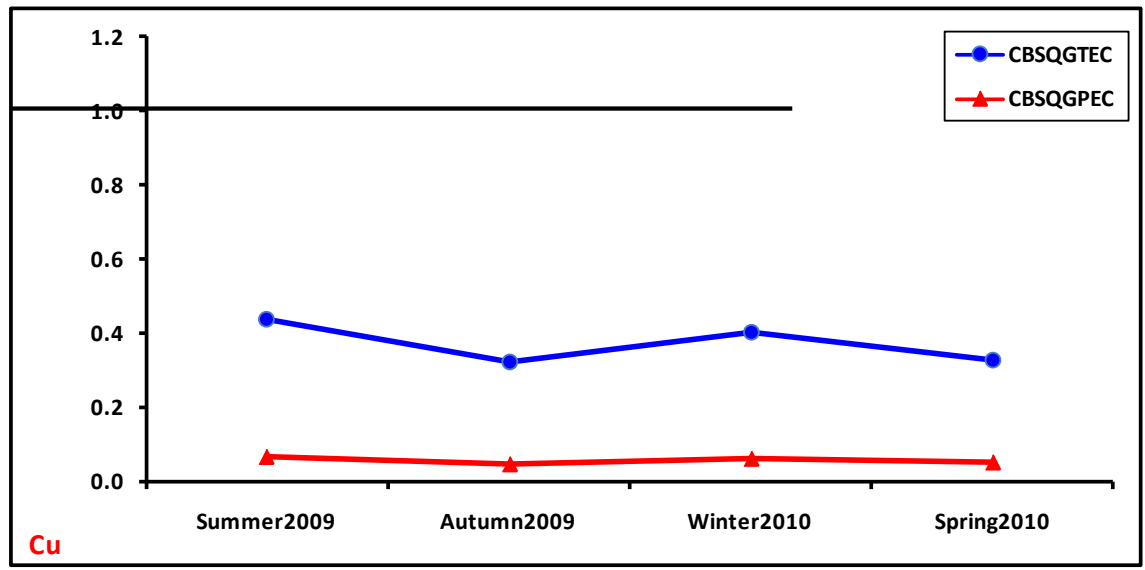

Figure 5. CBSQTEC and CBSQPEC for $\mathrm{Cu}$ in sediment samples collected from MarsaMatrouh beaches. 


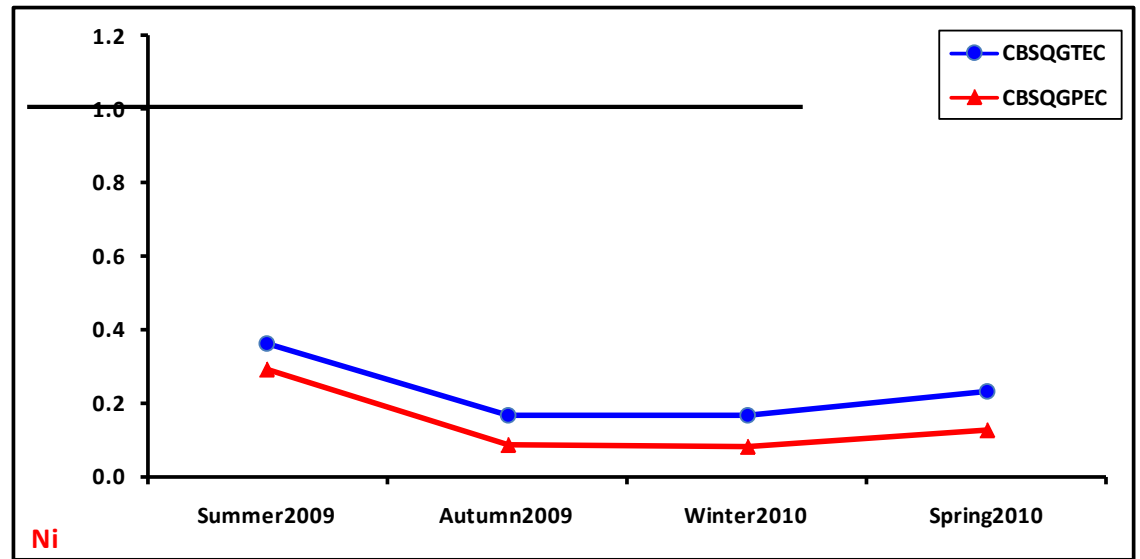

Figure 6. CBSQTEC and CBSQPEC for Ni in sediment samples collected from MarsaMatrouh beaches.

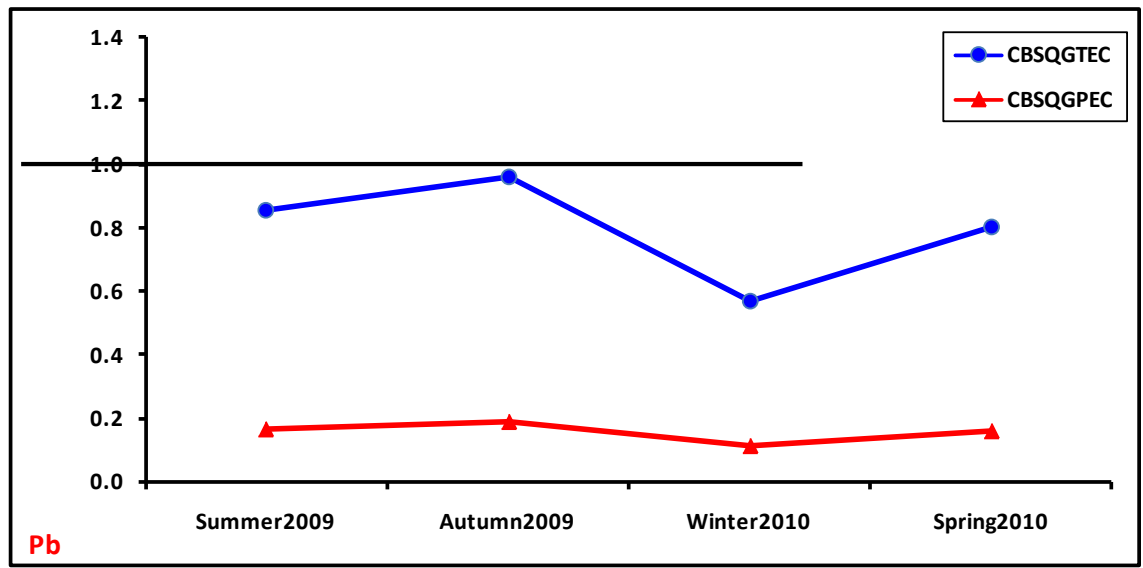

Figure 7. CBSQTEC and CBSQPEC for $\mathrm{Pb}$ in sediment samples collected from MarsaMatrouh beaches.

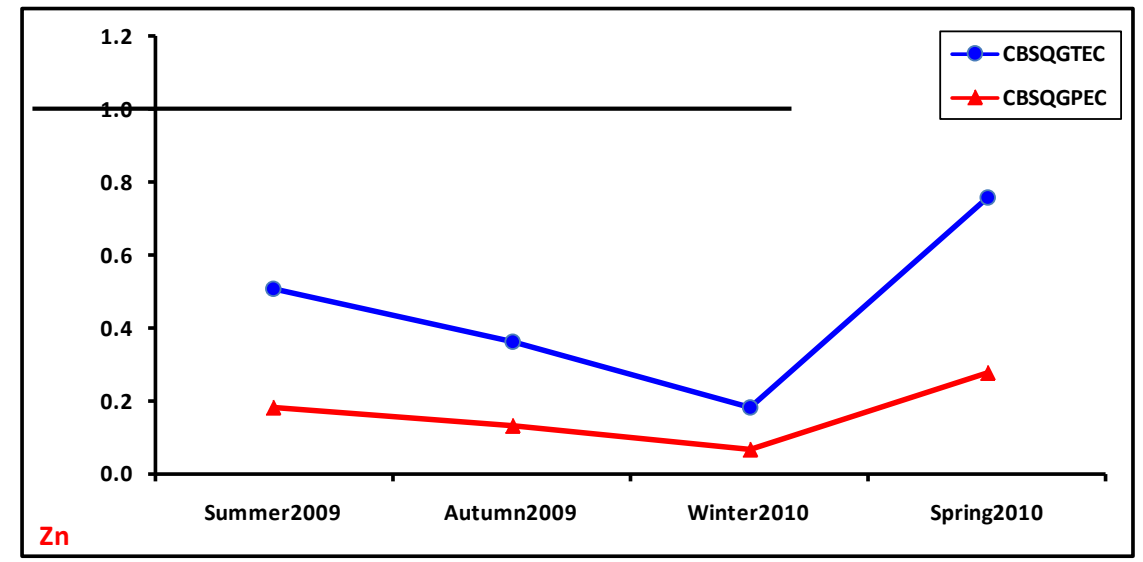

Figure 8. CBSQTEC and CBSQPEC for $\mathrm{Zn}$ in sediment samples collected from MarsaMatrouh beaches.

showed that all sediment samples fall in class 0 for $\mathrm{Cu}, \mathrm{Fe}, \mathrm{Ni}, \mathrm{Pb}$, and $\mathrm{Zn}$ indicating that Marsa-Matrouh City is not contaminated area for these metals during the period of study (Table 10). On the other hand, $80 \%$ of stations recorded 
fall in class 2 indicating that these stations are moderately contaminated with $\mathrm{Cd}$ and the other two stations (Stations 4 and 6) fall in class zero and classified as uncontaminated with $\mathrm{Cd}$.

\subsubsection{Statistical Analysis}

By applying the Pearson rank order correlations, the results revealed that the $\mathrm{Cu}$ in sediment is well correlated with $\mathrm{Pb}$ and $\mathrm{Zn}$ (0.878 and 0.634 respectively). Furthermore, there is a correlation between the $\mathrm{Zn}$ and $\mathrm{Pb}(0.768)$, between $\mathrm{Fe}$ and $\mathrm{Cu}, \mathrm{Pb}, \mathrm{Ni}(0.806,0.644,0.635$ respectively) as showed by Table 6 . On the other hand, there are significant correlations between each of dissolved form of $\mathrm{Fe}$ and $\mathrm{Ni}$ and their corresponding concentration in the sediment (0.574 and 0.551 respectively).

1) Principal component analysis

Multivariate analysis (Principal component analysis, PCA) has been applied on the data set for ten sediment samples and six variables $(\mathrm{Cd}, \mathrm{Cu}, \mathrm{Pb}, \mathrm{Ni}, \mathrm{Zn}$ and $\mathrm{Fe}$ ). R-mode factor analysis with VARIMAX rotation with Kaiser Normalization, as well as the Eigen values was applied to the previous inorganic pollutants in the sediment samples (Table 11). PC1 and PC2 account for 54.608 and $23.013 \%$ of the total variance, respectively. $\mathrm{PC} 1$ has high loadings of $\mathrm{Cu}, \mathrm{Pb}$ and $\mathrm{Fe}$; moderate loading of $\mathrm{Ni}$ and $\mathrm{Zn}$. PC2 is loaded on Cd only.

2) Cluster analysis

By applying, the cluster analysis for both the complete and centroid linkages. Similar relations between pollutants were obtained by the two studied clustering methods. The resultant dendrograms confirm the results obtained with PCA. Indeed, there were five clusters, which can be identified as follows: the first cluster $(\mathrm{A})$ contains $(\mathrm{Cu}$ and $\mathrm{Pb})$ at distance 1 , at a higher distance (about 5) $\mathrm{Fe}$ is fused with cluster (A) formed cluster (B). At distances 7 and 11, $\mathrm{Zn}$ and $\mathrm{Ni}$ are also fused with cluster (A) forming cluster (D). All these clusters appear at Factor 1. At very high distance $25, \mathrm{Cd}$ is fused with cluster (D) forming cluster (E) (Figure 9).

Table 10. Geo-accumulation Index of $\mathrm{Cd}, \mathrm{Cu}, \mathrm{Fe}, \mathrm{Ni}, \mathrm{Pb}$ and $\mathrm{Zn}$.

\begin{tabular}{ccccccc}
\hline \multirow{7}{*}{ Station } & \multicolumn{7}{c}{ Igeo } \\
\cline { 2 - 7 } & $\mathrm{Cd}$ & $\mathrm{Cu}$ & $\mathrm{Fe}$ & $\mathrm{Ni}$ & $\mathrm{Pb}$ & $\mathrm{Zn}$ \\
\hline 1 & 1.114 & -2.067 & -4.334 & -3.013 & -0.934 & -2.044 \\
2 & 1.075 & -2.133 & -5.314 & -3.043 & -0.915 & -2.231 \\
3 & 1.171 & -2.278 & -5.809 & -1.391 & -1.152 & -1.880 \\
4 & 0.615 & -1.539 & -2.676 & -2.022 & -0.609 & -1.346 \\
5 & 1.796 & -1.394 & -4.241 & -2.131 & -0.101 & -1.439 \\
6 & 0.704 & -2.000 & -5.504 & -2.900 & -0.393 & -1.149 \\
7 & 1.136 & -2.421 & -1.784 & -1.405 & -0.328 & -1.488 \\
8 & 1.351 & -2.313 & -6.196 & -3.227 & -0.104 & -2.064 \\
9 & 1.746 & -2.358 & -6.381 & -3.484 & -0.182 & -2.382 \\
10 & 1.967 & -1.847 & -5.639 & -2.504 & -0.067 & -2.311 \\
\hline
\end{tabular}


Table 11. VARIMAX normalization rotated factor loading for three factors obtained according to pollutants in the sediment samples along Matrouh Beaches.

\begin{tabular}{ccc}
\hline Variable & Factor 1 & Factor 2 \\
\hline $\mathrm{Cd}$ & -0.095 & -0.977 \\
$\mathrm{Cu}$ & $\mathbf{0 . 9 7 6}$ & -0.017 \\
$\mathrm{~Pb}$ & $\mathbf{0 . 8 9 0}$ & 0.105 \\
$\mathrm{Ni}$ & $\mathbf{0 . 6 1 2}$ & 0.230 \\
$\mathrm{Zn}$ & $\mathbf{0 . 6 8 1}$ & 0.531 \\
$\mathrm{Fe}$ & $\mathbf{0 . 8 2 8}$ & 0.280 \\
Variance \% & 54.608 & 23.013 \\
Cumulative \% & 54.608 & 77.621 \\
\hline
\end{tabular}

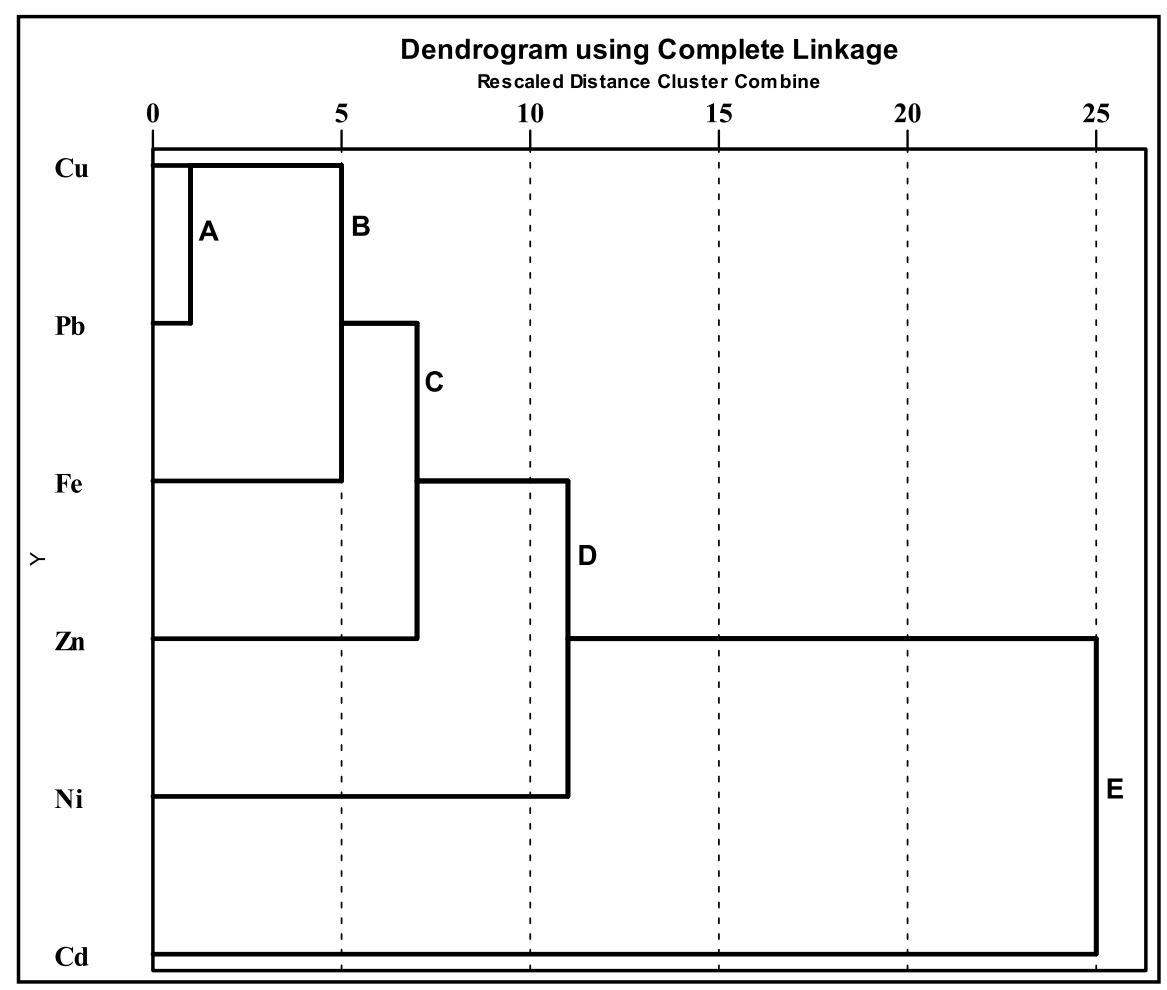

Figure 9. Dendogram obtained by hierarchical clustering analysis for metals in sediment samples.

\section{Conclusion}

Sediments are important hosts for trace metals and as such should be included in environmental monitoring programs. The investigation of sediments in Marsa-Matrouh city revealed that the investigated area is not enriched with $\mathrm{Cu}, \mathrm{Ni}$, $\mathrm{Pb}, \mathrm{Zn}$ and $\mathrm{Fe}$. On the other hand some locations along the city beach are relatively contaminated by $\mathrm{Cd}$ in their sediment samples but still lower than the frequent adverse ecological effects for benthic marine organisms. The spatial distribution of the different investigated metals showed that the area is influenced by the wastewaters discharged specially in summer season where the 
number of visitors increases to more than one million. Based on the above the results, establishment of few routine monitoring sites, especially near the major sources of pollution must be done. Prevention, reduction and control of pollution caused by discharges from land-based activities and shipping activities could be greatly helpful in the improvement and the future management of the Marsa-Matrouh beaches.

\section{References}

[1] Villares, R., Puente, X. and Carballeira, A. (2003) Heavy Metals in Sandy Sediments of the RíasBaixas (NW Spain). Environmental Monitoring and Assessment, 83, 129 144. https://doi.org/10.1023/A:1022542416249

[2] Schropp, S.J. and Windom, H.L. (1988) A Guide to the Interpretation of Metal Concentrations in Estuarine Sediments. Savannah, Georgia, 53 p.

[3] Maher, W.A. and Aislabie, J. (1992) Polycyclic Aromatic Hydrocarbons in near Shore Marine Sediments of Australia. Science of the Total Environment, 112, 143164. https://doi.org/10.1016/0048-9697(92)90184-T

[4] El Nemr, A., El-Sikaily, A. and Khaled, A. (2007) Total and Leachable Heavy Metals in Muddy and Sandy Sediments of Egyptian Coast along Mediterranean Sea. Environmental Monitoring and Assessment, 129, 151-168. https://doi.org/10.1007/s10661-006-9349-8

[5] Tam, N.F.Y. and Wong, Y.S. (2000) Spatial Variation of Heavy Metals in Surface Sediments of Hong Kong Mangrove Swamps. Environmental Pollution, 110, 195 205. https://doi.org/10.1016/S0269-7491(99)00310-3

[6] Diagomanolin, V., Farhang, M., Ghazi-Khansari, M. and Jafarzadeh, N. (2004) Heavy Metals (Ni, Cr, Cu) in the Karoon Waterway River, Iran. Toxicology Letters, 151, 63-68. https://doi.org/10.1016/j.toxlet.2004.02.018

[7] Ridgway, J. and Shimmield, G. (2002) Estuaries as Repositories of Historical Contamination and Their Impact on Shelf Seas. Estuarine, Coastal and Shelf Science, 55, 903-928. https://doi.org/10.1006/ecss.2002.1035

[8] Solomons, W. and Förstner, U. (1984) Metals in the Hydrocycle. Springer Verlag, Berlin, 349 p. https://doi.org/10.1007/978-3-642-69325-0

[9] Pandey, P., Nair, S., Bhui, A. and Pandey, M. (2004) Sediment Contamination by Arsenic in Parts of Central-East India and Analytical Studies on Its Mobilization. Current Science, 86, 190-197.

[10] Hakanson, L. (1980) An Ecological Risk Index for Aquatic Pollution Control. A Sedimentological Approach. Water Research, 14, 975-1001.

https://doi.org/10.1016/0043-1354(80)90143-8

[11] RivailDaSilva, M., Lamotte, M., Donard, O.F.X., Soriano-Sierra, E.J. and Robert, M. (1996) Metal Contamination in Surface Sediments of Mangroves, Lagoons and Southern Bay in Florianopolis Island. Environmental Technology, 17, 1035-1046. https://doi.org/10.1080/09593331708616473

[12] Soares, H.M.V.M., Boaventura, R.A.R., Machado, A.A.S.C. and EstevesDaSilva, J.C.G. (1999) Sediments as Monitors of Heavy Metal Contamination in the Ave River BASIN (Porugal): Multivariate Analysis of Data. Environmental Pollution, 105, 311-323. https://doi.org/10.1016/S0269-7491(99)00048-2

[13] Wright, P. and Mason, C.F. (1999) Spatial and Seasonal Variation in Heavy Metals in the Sediments and Biota of Two Adjacent Estuaries, the Orwell and the Stour, in Eastern England. Science of the Total Environment, 226, 139-156. 
https://doi.org/10.1016/S0048-9697(98)00383-0

[14] Zoumis, T., Schmidt, A., Grigorova, L. and Calmano, W. (2001) Contaminants in Sediments: Remobilisation and Demobilisation. Science of the Total Environment, 266, 195-202. https://doi.org/10.1016/S0048-9697(00)00740-3

[15] Horsfall, M. and Spiff, A. (2002) Distribution and Partitioning of Trace Metals in Sediments of the Lower Reaches of the New Calabar River, Port Harcourt, Nigeria. Environmental Monitoring and Assessment, 78, 309-326. https://doi.org/10.1023/A:1019991020048

[16] Izquierdo, C., Usero, J. and Gracia, I. (1997) Speciation of Heavy Metals in Sediments from Salt Marshes on the Southern Atlantic Coast of Spain. Marine Pollution Bulletin, 34, 123-128. https://doi.org/10.1016/S0025-326X(96)00059-8

[17] Li, X., Shen, Z., Wai, O. and Li, Y. (2001) Chemical Forms of Pb, Zn and Cu in the Sediment Profiles of the Pearl River Estuary. Marine Pollution Bulletin, 42, 215-223. https://doi.org/10.1016/S0025-326X(00)00145-4

[18] Patra, M., Bhowmik, N., Bandopadhyay, B. and Sharma, A. (2004) Comparison of Mercury, Lead and Arsenic with Respect to Genotoxic Effects on Plant Systems and the Development of Genetic Tolerance. Environmental and Experimental Botany, 52, 199-223. https://doi.org/10.1016/j.envexpbot.2004.02.009

[19] Buccolieri, A., Buccolieri, G., Cardellicchio, N., Dell'Atti, A., Di Leo, A. and Maci, A. (2006) Heavy Metals in Marine Sediments of Taranto Gulf (Ionian Sea, Southern Italy). Marine Chemistry, 99, 227-235. https://doi.org/10.1016/j.marchem.2005.09.009

[20] Algan, A.O., Çağatay, M.N., Sarikaya, H.Z., balkis, N. and Sari E. (1999) Pollution Monitoring Using Marine Sediments: A Case Study on the Istanbul Metropolitan Area. Turkish Journal of Engineering and Environmental Sciences, 23, 39-48.

[21] http://en.wikipedia.org/wiki/Mersa_Matruh

[22] Kremling, K. (1983) Determination of Trace Metals. In: Grassoff, K., Ed., Methods of Seawater Analysis, Vol. 303, Verlag Cheime, Weinheim, 225-227.

[23] Riley J.P. and Taylor, D. (1968) Chelating Resins for the Concentrations of Trace Elements from Seawater and Their Analytical Use in Conjunction with Atomic Absorption Spectrophotometer. Analytica Chimica Acta, 40, 479-485. https://doi.org/10.1016/S0003-2670(00)86764-1

[24] Kingston, H.M., Barnes, I.L., Brady, T.J., Rains, T.C. and Champ, M.A. (1978) Separation of Eight Transition Elements from Alkali and Alkaline Earth Elements in Estuarine and Seawater with Chelating Resin and Their Determination by Graphite Furnace Atomic Absorption Spectrometry. Analytical Chemistry, 50, 2065-2070.

[25] Amini Ranjbar, G.H. (1998) Heavy Metal Concentration in Surficial Sediments from Anzali Wetland, Iran. Water, Air, and Soil Pollution, 104, 305-312.

[26] Oregioni, B. and Astone, S.R. (1984) The Determination of Selected Trace Metals in Marine Sediments by Flameless/Flame-Atomic Absorption Spectrophotometry. Internal Report, IAEA Monaco Laboratory, Monaco City.

[27] Mohan S.V., Nithila, P. and Reddy, S.J. (1996) Estimation of Heavy Metal in Drinking Water and Development of Heavy Metal Pollution Index. Journal of Environmental Science and Health, Part A, 31, 283-289.

[28] Prasad B. and Kumari S. (2008) Heavy Metal Pollution Index of Ground Water of an Abandoned Open Cast Mine Filled with Fly Ash: A Case Study. Mine Water and the Environment, 27, 265-267. https://doi.org/10.1007/s10230-008-0050-8

[29] Reza R. and Singh, G. (2010) Assessment of Heavy Metal Contamination and Its Indexing Approach for River Water. International Journal of Environmental Sci- 
ence and Technology, 7, 785-792. https://doi.org/10.1007/BF03326187

[30] Drinking Water Specification: IS: 10500, 1992, Reaffirmed 1993.

[31] Swartz, R.C. (1999) Consensus Sediment Quality Guidelines for Polycyclic Aromatic Hydrocarbon Mixtures. Environmental Toxicology and Chemistry, 18, 780-787. https://doi.org/10.1002/etc.5620180426

[32] MacDonald, D.D., Ingersoll, C.G. and Berger, T.A. (2000a) Development and Evaluation of Consensus Based Sediment Quality Guidelines for Freshwater Ecosystems. Archives of Environmental Contamination and Toxicology, 39, 20-31. https://doi.org/10.1007/s002440010075

[33] MacDonald, D.D., Dipinto, L.M., Field, J., Ingersoll, C.G. and Long, E.R. (2000b) Development and Evaluation of Consensus-Based Sediment Effect Concentrations for Polychlorinated Biphenyls. Environmental Toxicology and Chemistry, 19, 1403 1413. https://doi.org/10.1002/etc.5620190524

[34] Long, E.R. and Morgan, L.G. (1991) The Potential for Biological Effects of Sediment-Sorbed Contaminants Tested in the National Status and Trends Program, NOAA Technical Memorandum NOS OMA 52, National Oceanic and Atmospheric Administration.

[35] Ingersoll, C.G., Haverland, P.S., Brunson, E.L., Canfield, T.J., Dwyer, F.J., Henke, C.E., Kemble, N.E. and Mount, D.R. (1996a) Calculation and Evaluation of Sediment Effect Concentrations for the Amphipod Hyalellaazteca and the Midge Chironomusriparius. Assessment and Remediation of Contaminated Sediments (ARCS) Program. U.S. EPA Great Lakes National Program Office, Chicago.

[36] Ingersoll, C.G., Haverland, P.S., Brunson, E.L., Canfield, T.J., Dwyer, F.J., Henke, C.E., Kemble, N.E., Mount, D.R. and Fox, R.G. (1996b) Calculation and Evaluation of Sediment Effect Concentrations for the Amphipod Hyalellaazteca and the Midge Chironomusriparius. Journal of Great Lakes Research, 22, 602-623.

https://doi.org/10.1016/S0380-1330(96)70984-X

[37] United States Environmental Protection Agency/National Oceanic and Atmospheric Administration (USEPA/NOAA) (2005) Predicting Toxicity to Amphipods from Sediment Chemistry. National Center for Environmental Assessment. Office of Research and Development, Washington DC.

[38] Smith, S.L., MacDonald, D.D., Keenleyside, K.A., Ingersoll, C.G. and Field, J. (1996) A Preliminary Evaluation of Sediment Quality Assessment Values for Freshwater Ecosystems. Journal of Great Lakes Research, 22, 624-638.

[39] Barrick, R., Becker, S., Brown, L., Beller, H. and Pastorok, R. (1988) Sediment Quality Values Refinement: Update and Evaluation of Puget Sound AET. Prepared for U.S. Environmental Protection Agency, Region 10-Office of Puget Sound, PTI Environmental Services, Bellevue.

[40] Müller, G. (1979) Schwermetalle in den sediments des Rheins-Veranderungenseitt 1971. Umschan, 79, 778-783.

[41] Müller, G. (1981) Die Schwermetallbelastung der sedimente des Neckars und seiner Neben.usse: Eine Bestandsaufnahme. Chemical Zeitung, 105, 157-164.

[42] Bakaç, M. (2000) Factor Analysis Applied to a Geochemical Study of Suspended Sediments from the Gediz River, Western Turkey. Environmental Geochemistry and Health, 22, 93-111. https://doi.org/10.1023/A:1006773305149

[43] El Nemr, A. and Abd-Alla, A.M.A. (2004) Organochlorines Contamination in Some Marketable Fish in Egypt. Chemosphere, 54, 1401-1406.

https://doi.org/10.1016/j.chemosphere.2003.10.041

[44] El Nemr, A., Khaled, A. and El-Sikaily, A. (2006) Distribution and Statistical Analy- 
sis of Leachable and Total Heavy Metals in the Sediments of the Suez Gulf. Environmental Monitoring and Assessment, 118, 89-112. https://doi.org/10.1007/s10661-006-0985-9

[45] El Nemr, A., Mohamed, F.A., El-Sikaily, A., Khaled, A. and Ragab, S. (2012a) Risk Assessment of Organochlorine Pesticides and PCBs Contaminated in Sediment of Lake Bardawell, Egypt. Blue Biotechnology Journal, 1, 405-422.

[46] El Nemr, A., Moneer, A.A., El-Sikaily, A. and Khaled, A. (2012b) PCBs and Pesticides in the Soft Tissue of Bivalves along the Coast of North Egypt. Blue Biotechnology Journal, 1, 301-313.

[47] El Nemr, A., Khaled, A. and El-Sikaily, A. (2012c) Metal Pollution in Surface Sediments along Egyptian Mediterranean Coast. Blue Biotechnology Journal, 1, 113 140 .

[48] El Nemr, A., Moneer, A.A., Khaled, A. and El-Sikaily, A. (2013) Levels, Distribution and Risk Assessment of Organochlorines in Surficial Sediments of the Red Sea Coast, Egypt. Environmental Monitoring and Assessment, 185, 4835-4853. https://doi.org/10.1007/s10661-012-2907-3

[49] Fifield, F.W. and Haines, P.J. (2000) Environmental Analytical Chemistry. 2nd Edition, Blackwell Science Ltd., Cambridge.

[50] CF (Committee for Fisheries) (1993) List of Maximum Allowable Concentrations and Approximately Harmless Levels of Impact of Toxic Chemicals on Water Bodies of Fisheries Importance. Kolos, Moscow.

[51] EC (European Commission) (1998) Quality of Bathing Water (1997). Document EUR 18166, European Commission, Brussels.

[52] Sunda W.G. and Huntsman, S.A. (1995) Iron Uptake and Growth Limitation in Oceanic and Coastal Phytoplankton. Marine Chemistry, 50, 189-206.

https://doi.org/10.1016/0304-4203(95)00035-P

[53] CCME (Canadian Council of Ministers of the Environment) (1992) Canadian Water Quality Guidelines, Prepared by the Task Force on Water Quality. Guidelines of the Canadian Council of Ministers of the Environment, Eco-Health Branch, Ottawa.

[54] Warren L.A. and Zimmerman A.P. (1994) The Influence of Temperature and $\mathrm{NaCl}$ on Cadmium, Copper and Zinc Partitioning among Suspended Particulate and Dissolved Phases in an Urban River. Water Research, 28, 1921-1931. https://doi.org/10.1016/0043-1354(94)90167-8

\section{Submit or recommend next manuscript to SCIRP and we will provide best service for you:}

Accepting pre-submission inquiries through Email, Facebook, LinkedIn, Twitter, etc. A wide selection of journals (inclusive of 9 subjects, more than 200 journals) Providing 24-hour high-quality service User-friendly online submission system Fair and swift peer-review system Efficient typesetting and proofreading procedure Display of the result of downloads and visits, as well as the number of cited articles Maximum dissemination of your research work

Submit your manuscript at: http://papersubmission.scirp.org/

Or contact jep@scirp.org 